\title{
The leaning Puy de Dôme (Auvergne, France) tilted by shallow intrusions
}

\author{
Michael S. Petronis ${ }^{* \alpha}$, Benjamin van Wyk de Vries ${ }^{\beta}$, Daniel Garza $^{\alpha}$ \\ ${ }^{\alpha}$ Environmental Geology, Natural Resources Management Department, New Mexico Highlands University, \\ Las Vegas, New Mexico, 87701, USA. \\ $\beta$ Université Clermont Auvergne, Observatoire du Physique du Globe de Clermont, \\ Laboratoire Magmas et Volcans, UMR6524-CNRS
}

\begin{abstract}
Monogenetic lava domes are a special type of volcanic structure, prone to mass wasting and explosive eruption hazards. The existence of such domes raises fundamental questions about the nature of monogenetic volcanism. We study the iconic Puy de Dôme (Chaîne des Puys, Auvergne) that gave its name to 'dome' landforms. It is asymmetric with one side more rugged and steeper than the other. The Puy de Dôme grew rapidly in one simple pulse from a bulging shallow intrusion, the Petit Puy de Dôme, and then solidified in situ. Using mapping and paleomagnetism we find that it was subsequently tilted by $\sim 17^{\circ}$ to the southwest by further surface-bulging inflation of the Petit Puy de Dôme intrusion. During the tilting, there were landslides and there was a final small phreatomagmatic eruption. The dome's history verges on polygenetic, spanning several hundred years of intrusion and eruption, extending hazard periods for such activity. We find other intrusive uplifts with paired domes and tilted cones both in the Chaîne des Puys and in other monogenetic and polygenetic systems.
\end{abstract}

\section{RÉSUMÉ}

Les dômes de lave monogéniques sont un type particulier de structure volcanique, qui sont souvent associés à des glissements et des événements explosifs. L'existence de telles structures remet en cause les principes fondamentaux du volcanisme monogénique. Nous étudions l'iconique Puy de Dôme (chaîne des Puys, Auvergne) qui a donné son nom à la forme géomorphologique connue comme 'dôme'. Il est asymétrique, avec un coté plus rugueux et pentu que l'autre. En utilisant de la cartographie et du paléomagnétisme, nous remarquons que le dôme fut basculé vers le sud-ouest par une intrusion superficielle, le Petit puy de Dôme, qui bomba la surface. Le puy de Dôme grossit rapidement à partir de cette intrusion, en un seul événement bref, se solidifia, et ensuite fût basculé à environ $17^{\circ}$. Pendant le basculement, des glissements de terrain se produisirent, suivis d'une ultime petite éruption phréatomagmatique. L'histoire du dôme s'approche de celui d'un volcan polygénique, avec une durée d'intrusion de plusieurs centaines d'années qui prolonge de manière considérable la période d'exposition aux aléas. Nous écrivons d'autres exemples de bombements intrusifs avec des dômes jumelés dans la chaîne des Puys et dans d'autres systèmes polygéniques et monogéniques.

Keywords: Chaîne des Puys; Paleomagnetism; Lava dome; Polygenetic volcanism; Puy de Dôme

\section{InTRODUCTION}

Lava domes are a type of volcanic landform with very particular dynamics and hazards [Calder et al. 2015]. Monogenetic lava domes are a special class of dome, which by nature of their short, single eruption tend to preserve any evidence of processes that might otherwise be destroyed by subsequent eruptions in polygenetic volcanoes [Németh 2010]. Yet such short-lived monogenetic domes can have very complex histories and they are useful analogues for larger polygenetic systems [Kereszturi and Nmeth 2012; Valentine et al. 2017].

Of equal interest to domes are uplift structures produced by near-surface magma intrusion, which are

\footnotetext{
${ }^{*}$ Corresponding author: mspetro@nmhu.edu
}

also well-preserved in monogenetic volcanic fields [van Wyk de Vries et al. 2014], and are found to be common in many settings [e.g. Reeves et al. 2018; Magee et al. 2017]. These structural domes were originally termed 'craters of elevation' [von Buch 1820], and in structural geology these features are called 'forced folds' [Cosgrove and Hillier 1999], or in volcanology the terms 'bulges' and 'cryptodomes' have been used [Minakami et al. 1951; Gorshkov 1959; Moore and Albee 1981]. In this article, we have chosen to use the term 'bulge', as we are dealing with a surface morphological feature, while we keep in mind that for structural geology we have a forced fold. Importantly, bulge features are known to deform volcanic structures, and the underlying intruding magma can also break the surface and be erupted [Minakami et al. 1951; Magee et al. 2017]. Thus, bulges and their intrusions are shallow 
sources of potentially explosive magma, which merit study as they are obvious harbingers of hazard, and are clearly identifiable as they bulge up. The Usu domes [e.g. Minakami et al. 1951] — probably the most famous polygenetic active shallow intrusion, bulge and dome system-are part of a UNESCO Global Geopark, where the cycle of bulging, eruption and recovery is a central theme for risk awareness [Okada et al. 2016; Nakada 2018].

The study of near surface intrusion uplift and monogenetic edifice growth encompasses the essential question of how volcanoes form and how they erupt, a subject which has been debated since volcanology began. The Puy de Dôme in the Chaîne des Puys (Central France) is a classic monogenetic volcanic dome, and its name is one of the origins of the term 'volcanic dome', in use since the Puy de Dôme was recognized as a volcano in the mid $18^{\text {th }}$ Century [Guettard 1752]. It has been a focus of volcanological study since this time, as the Chaîne des Puys has continually attracted the attention of scientists by virtue of the diversity of volcanic features, its accessibility, and its particular visibility on a plateau above the Limagne Rift. This clarity of expression has led to the 'Chaîne des Puys-Limagne fault tectonic arena' being included on the UNESCO World Heritage list in 2018 for riftingrelated tectonics and magmatism, exemplified by the Puy de Dôme (van Wyk de Vries et al. [2012], UNESCO: http://whc.unesco.org/en/list/1434). The Puy de Dôme has recently been studied for the conditions of dome eruptive dynamics and structure [Miallier et al. 2010; Martel et al. 2013; Portal et al. 2016; Boudon et al. 2015; France et al. 2016], while its smaller neighbour, the Petit Puy de Dôme, has been studied for intrusion related uplift [van Wyk de Vries et al. 2014]. In this latter paper, the authors suggested that the dome's eruption was fed from the Petit Puy de Dôme intrusion that created the uplift, however this connection was not studied in detail.

Despite this recent attention, detailed knowledge of Puy de Dôme's emplacement history through structural mapping and especially the detailed geomorphology is lacking. The morphology of the the dome is intriguing: like the leaning tower of Pisa (also a World Heritage site), one side of the Puy de Dôme is steeper than the other, a feature that has attracted the attention of many geologists, and is the focus of our current investigations.

In this study, we have taken advantage of the increased interest in the area as a prospective UNESCO World Heritage site, which has promoted more detailed mapping and provided LiDAR data (openly available on CRAIG-Centre Regional d'Auvergne des Informations Géographiques: https://www.craig.fr/). The LiDAR comes from two datasets, that of the city of Clermont-Ferrand (5 $\mathrm{m}$ spacing), and from the $\mathrm{Li}^{-}$ dArverne campaign (0.5 m spacing).

Paleomagnetic data are a valuable complement to structural data, with which we expected to provide information on the rotation of parts of the dome after cooling. Thus, while mapping the dome we also collected drill core samples for paleomagnetic and anisotropy of magnetic susceptibility analysis (unfortunately these latter AMS data are inconclusive, but are included as an annex for completeness).

While the motivation for this study was initially to study the complexities of the growth of the Puy de Dôme and to compare these observations and data with other domes studied around the world [e.g. CarrascoNúñez and Riggs 2008; Duffield et al. 1995; Závada et al. 2009], we found quickly that the Puy de Dôme was best understood in context of its surrounding geology and that it was but one part of a prolonged intrusion and eruption event.

We expected from early field work to find evidence of complex rotations of parts of the dome as it grew. However, the paleomagnetic data did not support this hypothesis, suggesting a more simple growth with subsequent slow cooling for the dome itself. In contrast, a complex multistage eruption sequence was uncovered including associated features like the Petit Puy de Dôme, hinted at from earlier work [Miallier et al. 2010; van Wyk de Vries et al. 2014]. This activity started before the emplacement of the Puy de Dôme, with uplift and bulging, and it continued after the dome was formed. This late stage activity deformed and tilted the dome, causing faulting, collapse events and landslides, and creating its present morphology.

\subsection{Description of the Puy de Dôme}

The Puy de Dôme is the tallest volcano within the Chaîne des Puys at 1,465 m, and has remained for more than two millenia an iconic symbol for the region (on the summit there are the remains of the Roman temple of Mercury built circa 1st century BCE, probably over a previous Gaullish religious site) and is one of the most visited volcanic domes in the world [Jerram et al. 2017]. The Puy de Dôme is about 11,000 years old, and is one of the youngest volcanoes in the Chaîne des Puys (Figures 1 and 2). The Chaine des Puys is an $\sim 40 \mathrm{~km}$ long north-south trending alignment of monogenetic domes, cones, and maars that began erupting about 95,000 years ago [Camus et al. 1995; Boivin et al. 2017]. The Chaîne is built on the 'Plateau des Dômes', formed of Hercynian basement and it is parallel to the Limagne fault (Figure 1), which forms the western border of the Limagne rift, part of the larger European Cenozoic Rift System [Michon and Merle 2001].

The Puy de Dôme is a classic lava dome, with steep sides, a flat top, and a broad breccia apron (see Figure 2). Morphologically, it has two distinct sides that have been interpreted as two phases of growth and collapse [Camus et al. 1995; Camus 1975]. On the south and western flanks, the Puy de Dôme is rocky with steep slopes marked by radial ridges, and punctuated 


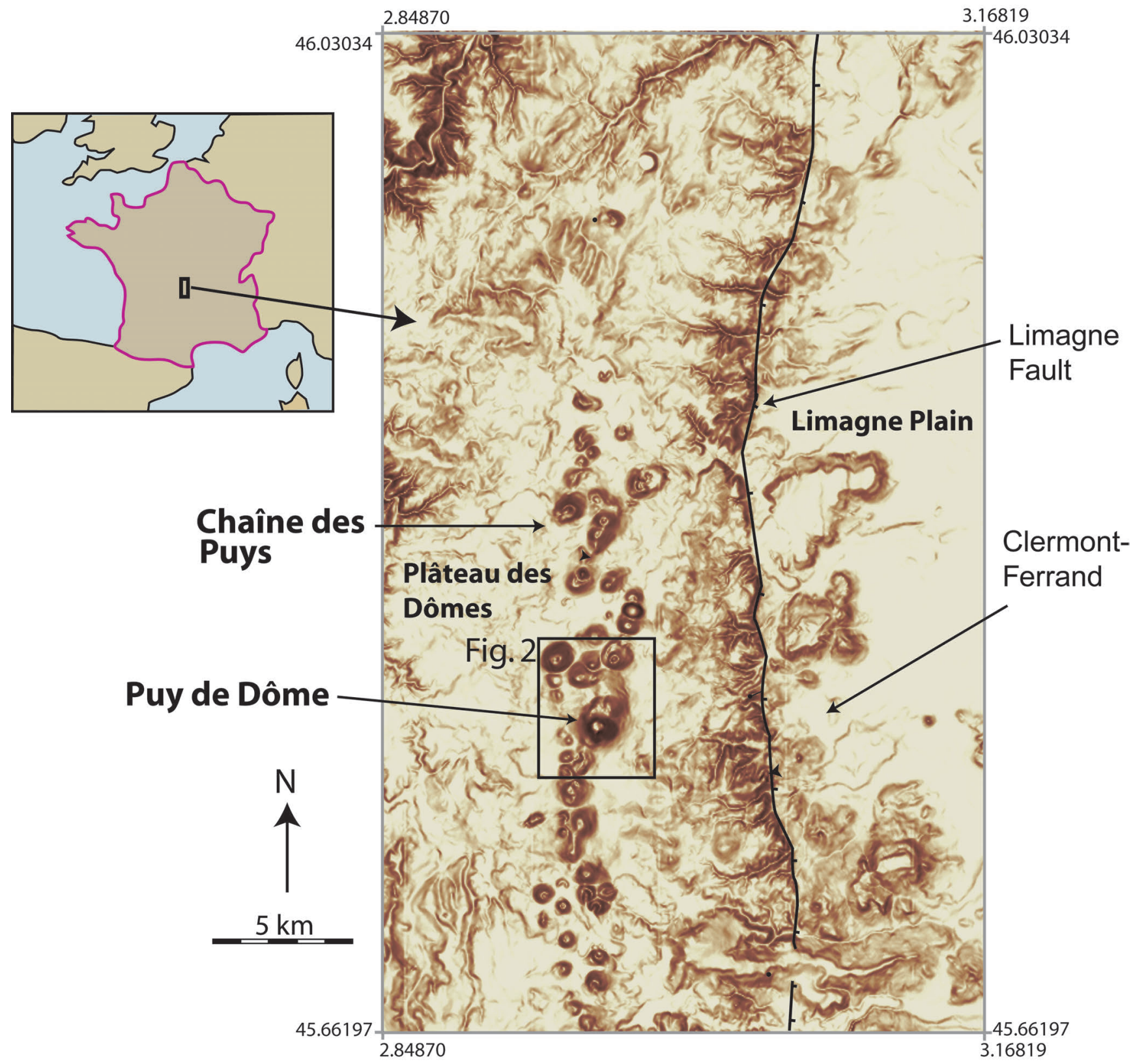

Figure 1: Location map of the Puy de Dôme, set in the Chaîne des Puys, aligned on the shoulder of the Limagne Rift, near Clermont-Ferrand. Their location within France, and the location of the geological map (Figure 2) are shown.

by small pinnacles or spine-like structures (Figures 3, 4, 5, 6 and 7). In contrast, the eastern flank of the Puy de Dôme is smooth and gently sloping and lacks the rugged nature of the south and western flanks (Figure 3 to Figure 7).

The north-east side was suggested to have been emplaced onto the eastern margin of the first dome after flank collapse [Camus 1975]. Alternatively, it has been suggested that the dome is mostly the product of one main eruption, which changed from endogenous to exogenous, covering the initial lava carapace and block and ash deposits with thick cemented ash layers on the northeast side from a final small eruption [Boivin et al.
2017].

The internal structure of the Puy de Dôme has been investigated with electromagnetic and gravity techniques and and muon tomography, revealing various zones of different degrees of fracturing and/or porosity arranged around a central conduit [Portal et al. 2016; Cârloganu et al. 2013]. The dome partially covers possibly two previous scoria cones, seen in geophysical data, called the Creux de la Berte (also visible in the landscape e.g. Figure 5), and another mostly hidden cone called the Cornebeuf [Boivin et al. 2017].

To the north-east of the dome the Petit Puy de Dôme is a prominent bulge formed by 10 s to 100 s of meters 


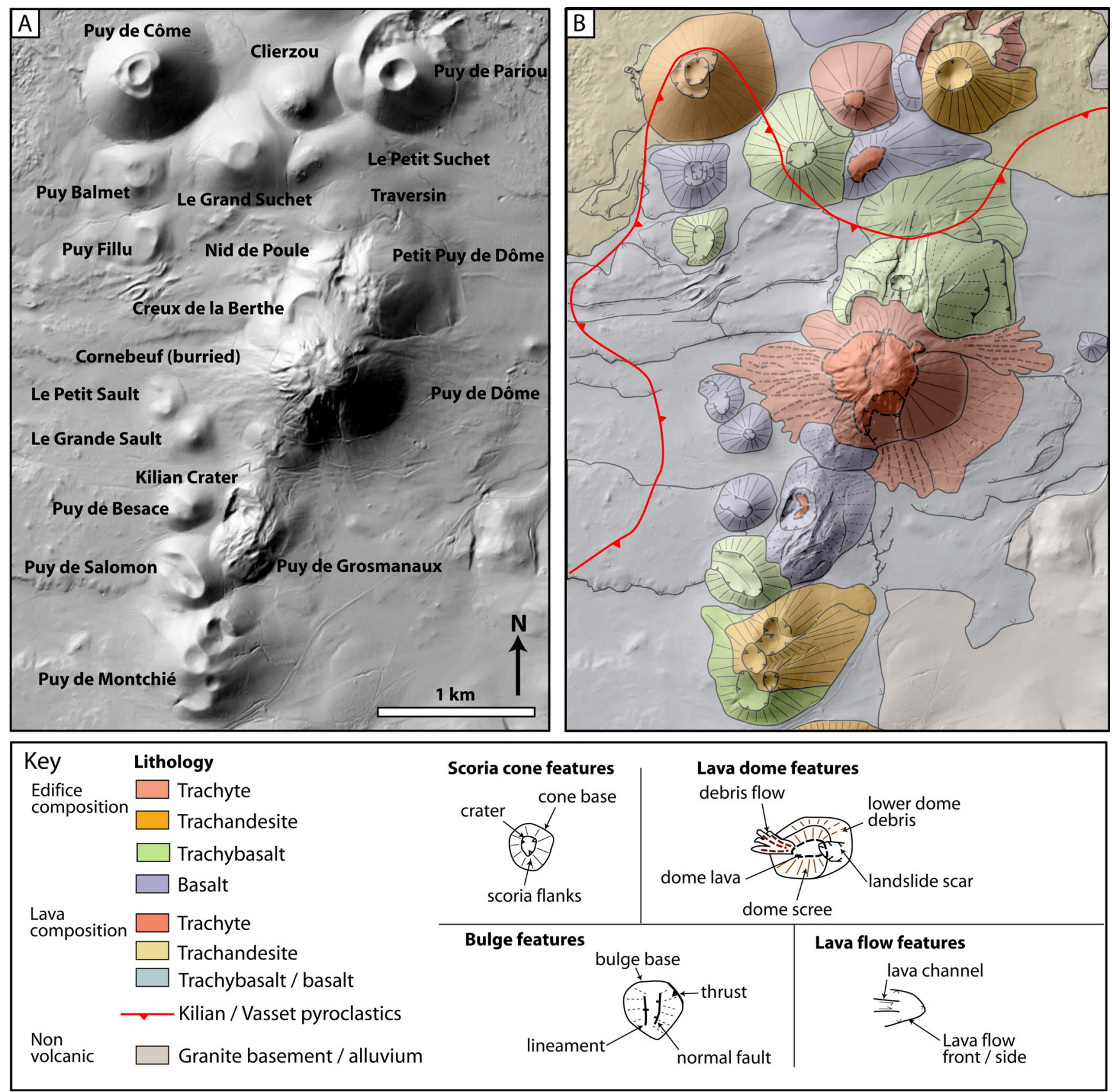

Figure 2: Topography and geology of the Puy de Dôme area. [A] Shaded relief image using the LiDAR data for Clermont-Ferrand (CRAIG dataset). [B] Geological map, based on the 'Volcanological map of the Chaîne des Puys' [Boivin et al. 2017], and previous fieldwork [van Wyk de Vries et al. 2014]. The Puy de Dôme is in the centre of the shaded relief image.

of bulging uplift over a shallow intrusion [van Wyk de Vries et al. 2014]. van Wyk de Vries et al. [2014] suggested that this bulge pierced the surface at the southwest to form the Puy de Dôme itself. The eruption age estimates of the Puy de Dôme range from $\sim 12,000$ $\mathrm{BP}$ to $\sim 9,700 \mathrm{BP}$ based on U-Th age determinations [Condomines 1997], thermoluminescence dating [Faïn et al. 1988; Faïn et al. 1988], and radiocarbon dates on peat deposits within and beneath the pyroclastic material [Juvigné and Gewelt 1987]. Most recently, using tephra chronology, Miallier et al. [2010] concluded that the Puy de Dôme was erupted at about 11,000 BP, and may have had two eruptions-the main dome forming event, and a later phreatic event (at about 10,700 BP) before being covered by a vulcanian pumice eruption from the Kilian crater $500 \mathrm{~m}$ to the south-west at 9,400 BP [Colombier et al. 2017].

The Puy de Dôme is composed of a greyish trachyte with phenocrysts of potassic oligoclase, sanidine, biotite, and rare green clinopyroxene [Condomines 1997]. Titanomagnetites were the likely initial oxide mineral phase but they have been extensively replaced 

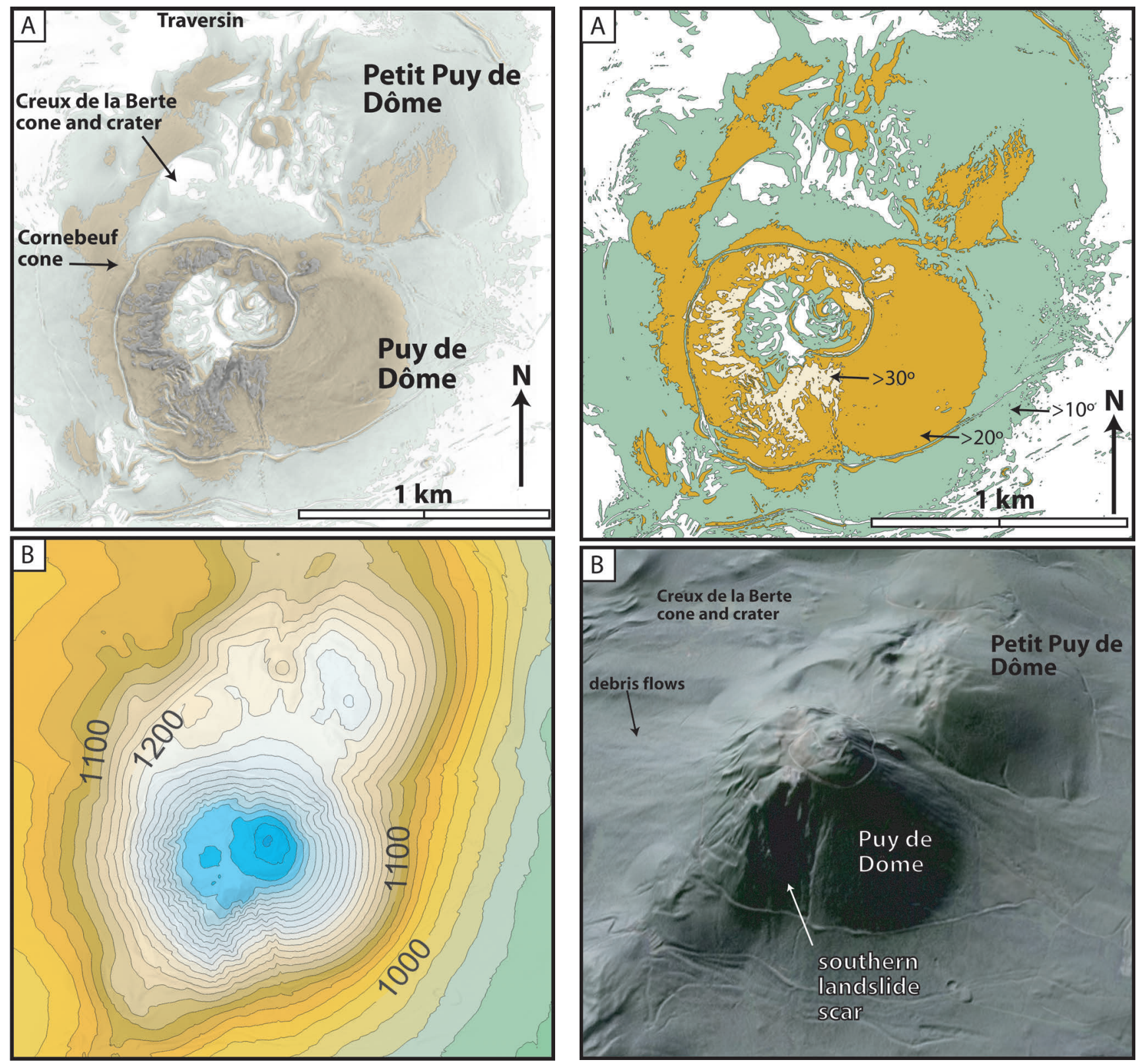

Figure 3: Maps of the Puy de Dôme. [A] Shaded relief map with transparent slope map overlay. This shows the steepest parts of the Puy de Dôme on the south-west side. [B] Contour map that shows the steep, closelyspaced crenulated contours on the south-west side, the smooth eastern contours, and the Petit Puy de Dôme bulge to the north-west.

by hematite [Condomines 1997]. Apatite and zircon crystals are found as inclusions within the feldspar or biotite crystals, and sometimes show epitactic growth [Condomines 1997].

\section{Methods}

\subsection{Field work ethics and protocol}

The Puy de Dôme is a protected area, and all sampling and fieldwork were carried out with prior permission

Figure 4: [A] Slope map (slopes above $20^{\circ}=$ Green, $30^{\circ}$ $=$ Brown, and $40^{\circ}=$ Yellow), showing the concentration of steep slopes on the west and south, while little over 30 in the eastern part. [B] Oblique image from Google Earth with the LiDAR data draped over in transparency. This shows the rugged south-west slopes, the dark, smooth east flank and the Petit Puy de Dôme. (C) 2019 Google.

from the many local landowners and protective bodies. These were the village commune of Ceyssat, who own the western flanks; the Puy de Dôme 'Grande Site'; the local Council of the Puy de Dôme UNESCO World Heritage project; the Puy de Dôme railway; and the Regional Park of the Auvergne Volcanoes. Field access was limited to minimise impact on the fragile geosystem and ecosystem of the volcano, which in many parts still reflects the natural state of the dome, which is slowly 


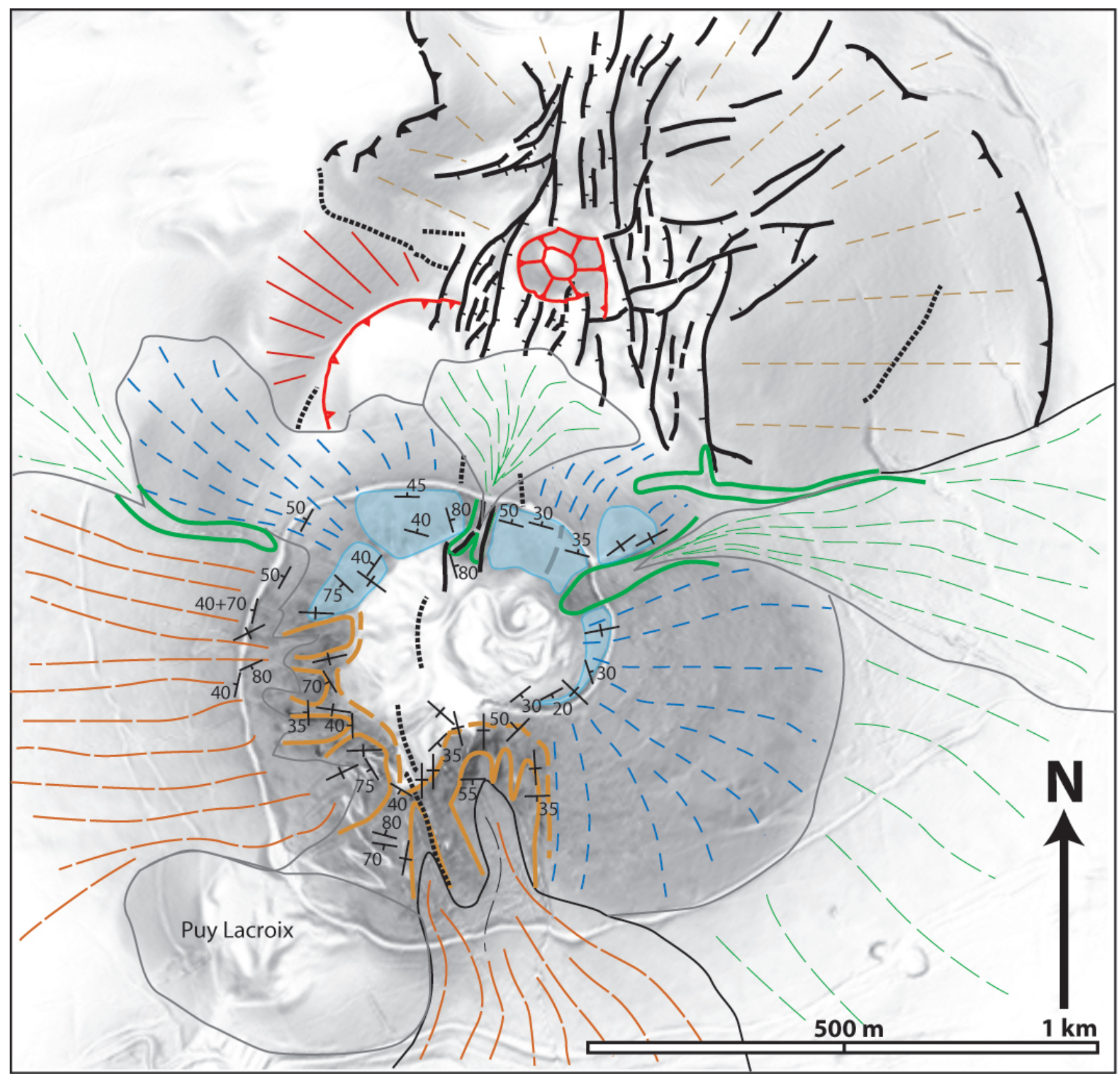

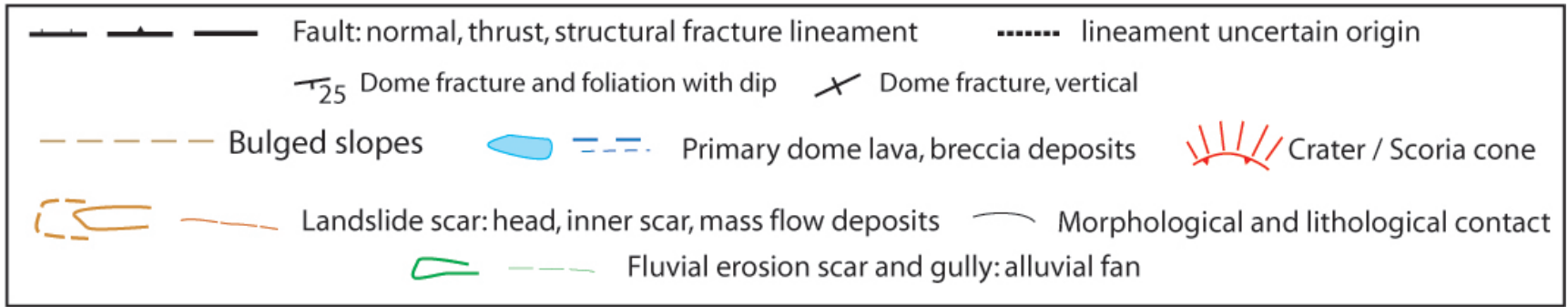

Figure 5: Morphological and structural map of the Puy de Dôme. Note the bulged area of the Petit Puy de Dôme, with its faulted area, and the Nid de la Poule crater inside the main graben. Note also the preponderance of landslide scars and debris flow deposits on the west and south of the Puy de Dôme and their lack on the smooth east side. Fracture and foliation data show two families: concentric down slope foliation with associated fractures, and radial vertical foliation and fractures. The vertical foliation is mostly seen near the top of the Puy de Dôme and on the south-west ridge. 


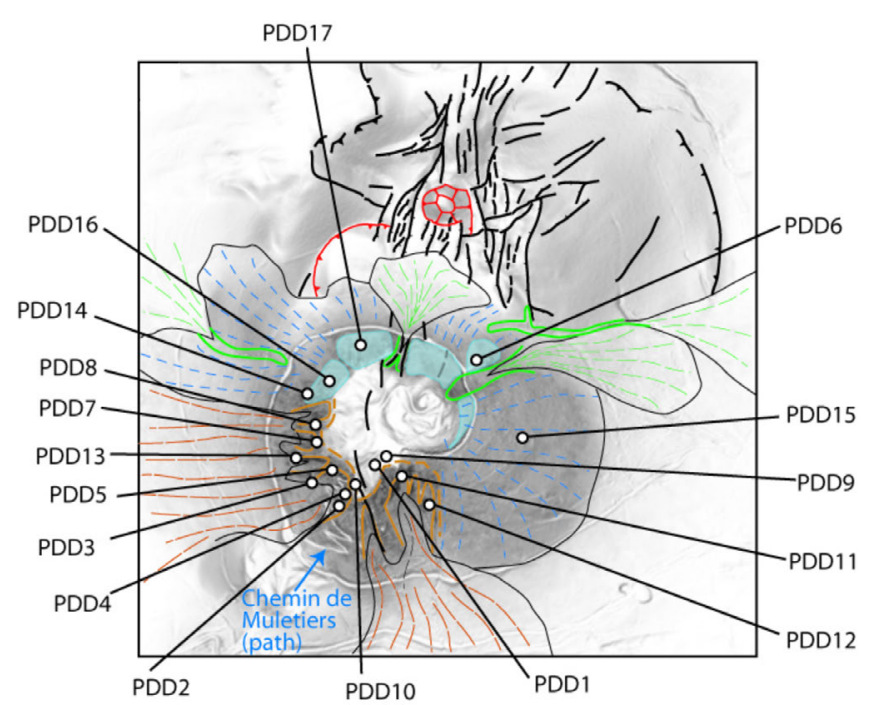

Figure 6: Location of the sample sites, given on the interpretative geomorphological map.

eroding and adjusting to 10,000 years of environmental change.

Sampling was done discreetly, mostly out of sight of the few paths, with a few holes left visible for educational purposes, as arranged with the UNESCO project. Drill core holes were not filled in, but left to blend into the rock surface, and now form very discreet features that require a keen eye to detect. The return of the sample sites to 'natural' conditions is monitored, and they are at present a subtle mark on rock surfaces, often covered by small plants, and providing niches for small animals.

The detailed work presented here serves also to enrich the general knowledge of the Puy de Dôme, and increase the geoheritage value, and through recognition of the various outcrop values, can allow for a more rigorous protection of the features. The maps and our experience can be integrated into a detailed geosite inventory, which would serve as a factual basis for informed management. The French national inventory of geoheritage [de Wever et al. 2015] does contain a Puy de Dôme geosite, which gives the fundamental description. However, despite this sound general foundation, we do have a concern that the geological and geoheritage values have yet to be fully integrated into the official protective practices, leaving the site exposed to disturbance far greater than our drill holes. There remains a need to communicate these geoheritage values, and hopefully this publication will go some way to emphasising the value of the Puy de Dôme, and stressing the need for strict geological conservation worthy of a UNESCO World Heritage site.

\subsection{Field and Remote Sensing Methods}

All sides of the Puy de Dôme were mapped in detail including all the geomorphological and the structural features, such as foliation, fractures, faults, and alteration. The geomorphology was also studied using detailed topographic maps and the LiDAR data, openly available from the CRAIG database ('LidArverne' data set: https://www.craig.fr/).

Eight to ten drill core samples were collected at each of seventeen sites (Figures 6 and 10) across the Puy de Dôme using a modified Echo 280E gasoline-powered drill with a non-magnetic diamond tip drill bit. All samples were oriented using a magnetic and, when possible, a sun compass. Drill site locations were precisely located using a 62st Garmin GPS.

All core samples were cut into $2.2 \times 2.5 \mathrm{~cm}$ cylindrical specimens, using a diamond tipped, non-magnetic saw blade with up to three specimens per core sample obtained at New Mexico Highlands University's Rock Processing laboratory.

\subsection{Laboratory Methods}

To identify magnetic mineral phases and the overall ability of these rocks to faithfully record an ambient magnetic field, we conducted a suite of laboratory experiments to characterise their magnetic remanence and anisotropy of magnetic susceptibility (AMS). These data are summarized in A. Equipment used included an AGICO JR6A dual-speed spinner magnetometer, homebuilt and ASC Scientific (Model IM-10-30) static impulse magnets capable of 1 to 3 Tesla peak fields, and a Quantum Design 7 Tesla magnetic properties measurement system. All susceptibility and Curie Point experiments were measured with an AGICO MFK1-A kappabridge susceptibility meter with a CS4 high temperature attachment at the New Mexico Highlands University Paleomagnetic - Rock Magnetic laboratory.

\subsubsection{Rock Magnetic Experiments}

Curie point experiments are used to establish the dominant magnetic mineral phase(s) present in the sample and to define the composition of the titanomagnetite phase(s). The samples are heated from room temperature to $700{ }^{\circ} \mathrm{C}$ and cooled down at a rate of $\sim 14^{\circ} \mathrm{C} \mathrm{min}^{-1}$ in an Argon atmosphere to minimize oxidation of the sample. To characterize the domain state of the magnetic minerals, we conducted isothermal remanent magnetization (IRM) and low temperature remanence experiments. The IRM acquisition experiments involve magnetizing a sample of near zero initial remanence in progressively higher peak applied fields using an impulse magnet until the specimen reaches saturation. The shape of the IRM acquisition curve provides data on the domain state and magnetic mineralogy.

To evaluate the stability of an induced remanence on cooling and warming, we performed FC and ZFC experiments. The low temperature experiments involved field cooled (FC), and zero field cooled (ZFC) experi- 

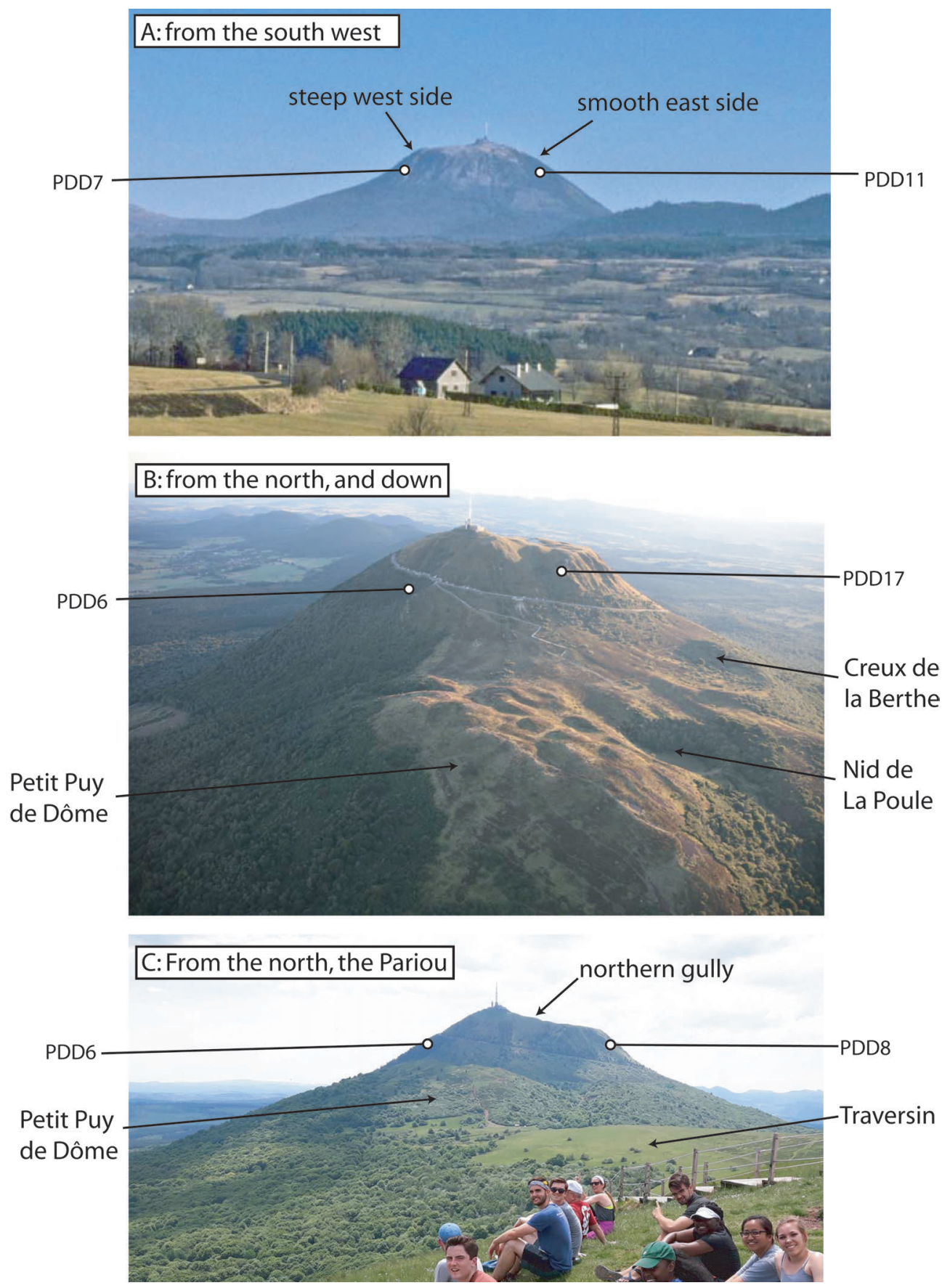

Figure 7: Views of the Puy de Dôme asymmetry from different vantage points, with selected sample points shown. [A] From the southwest. [B] Oblique aerial view from the north-northeast, looking over the Petit Puy de Dôme bulge. [C] From the Pariou volcano summit to the north-northeast, looking past the Petit Puy de Dôme. The northern gully of the Puy de Dôme is indicated. Location of viewpoints given in Figure 2.

ments with a Quantum Design 7 Tesla magnetic properties measurement system (MPMS). The MPMS experiments are used primarily for magnetic mineral identification based on low-temperature crystallographic transitions (e.g. the Verwey transition; Verwey [1939]), and for characterizing particle size distributions. The experiment involves the sample being cooled in a sustained DC field of $2.5 \mathrm{~T}$ to $10 \mathrm{~K}$. The field is then switched off at $10 \mathrm{~K}$ and the magnetic remanence is measured as the specimen warms back up to room temperature (FC remanence). The specimen is then subsequently cooled in a null magnetic field (ZFC) to $10 \mathrm{~K}$ where a low temperature saturation isothermal remanent magnetization is imparted using a $2.5 \mathrm{~T}$ applied field, and the remanence is measured again on warming back to room temperature (ZFC remanence). 


\subsubsection{Paleomagnetic Methods}

Remanent magnetizations of all samples were measured using an AGICO JR6A dual-speed spinner magnetometer at the New Mexico Highlands University Paleomagnetic-Rock Magnetic laboratory. Specimens were progressively demagnetized in an alternating field (AF), typically in 10 to 25 steps, to a maximum field of $120 \mathrm{mT}$ using an ASC Scientific D-TECH 2000 AF-demagnetizer. Samples with high coercivity were treated with thermal demagnetization $(\mathrm{TH})$ up to a maximum of $630{ }^{\circ} \mathrm{C}$, yet most sampleswere fully demagnetized below $580^{\circ} \mathrm{C}$. Thermal demagnetization experiments on replicate specimens, to compare with AF behavior, were conducted with an ASC Scientific TD48 thermal demagnetizer. Principal component analysis (PCA; Kirschvink [1980]) was used to determine the best-fit line through selected demagnetization data points for each sample using Remasoft 3.0 [Chadima and Hrouda 2006] (Table 1). For most samples, a single best-fit line could be fit to the demagnetization data points. Best-fit magnetization vectors generally comprised 5 to 18 data points, but as few as 3 to as many as 25 were occasionally used; for less than 10 $\%$ of the samples it was necessary to anchor them to the origin. Magnetization vectors with maximum angular deviation values greater than $5^{\circ}$ were not included in site mean calculations.

\section{Results}

\subsection{Field and Topographic Mapping Results}

The Puy de Dôme summit has low slopes, cut by small north-south trending scarps, and these flatter areas have been much modified by anthropogenic activity. In contrast, the steeper slopes retain the natural structural and morphological features of the dome (Figures 8, 9 and 10). The summit plateau has one high peak, which hosts a telecommunication antenna, the Observatoire de Physique du Globe de Clermont-Ferrand's (OPGC) meteorological observatory, and the ruins of a Roman temple of Mercury. Around this peak, there are outcrops of dome lava with dome breccia at the base. The breccia descends down the flanks to the base of the dome. The Kilian vulcanian deposits [Colombier et al. 2017], which erupted just after the Puy de Dôme formed, are found in patches on the lower slopes, the summit, and in topographical depressions [Miallier et al. 2010; Miallier et al. 2012].

On the eastern and northern slopes, the flanks are smooth, cut only by one pinnacle/spine-like feature of dome lava (Figures 3, 4, 5 and 6), and there are some narrow, deep erosional gullies from ephemeral streams that activate only during very strong rainfall (Figure 5). The gullies open onto alluvial fans, and these reworked slopes pass over a few hundreds of meters onto pre-Puy de Dôme lavas and tephra (Figures 2 and 6).
Only one outcrop on the mid eastern flank (PDD15) was large enough to be considered as in situ and was sampled. However, the good outcrop on the road shows the flank underlain by outward dipping foliated and fractured trachyte (Figure 9C).

The southern and eastern slopes of the dome are very different. Starting at the north-east, the dome lava outcrops are cut by a series of deep scars, leaving intervening ridges (Figures 5 and 8). The internal layering of the dome is uncovered, exposing down-slope dipping concentric foliation, and radial fractures with verticalsteep dips (Figures 9 and 10). The trachyte in most outcrops is dense, massive, and sometimes crumbly, and contains few conjugate fractures, although some heavily fractured zones exist. The best exposures of this are seen on the road to the summit (Figure 9C), where cuttings expose a $10 \mathrm{~s}-\mathrm{of}-\mathrm{cm}$-spaced conjugate fracture set, that in places has $\mathrm{cm}$-spaced fractures that form sets of about $60-80^{\circ}$ Riedel shears, and tension gashes between $20-30^{\circ}$ to the main fractures. The rock mass remains compact, so the structures probably formed when the rock was near the brittle-ductile transition. The rocks in this area contain only the widely spaced vertical fractures that cut the outward dipping foliation.

One particularly sizeable ridge on the south-west side has a series of large down-slope fractures at its base and several large open cracks on its upper side. This is buttressed on its lower edge by a large lava mass, but the the absence of lichen or other vegetation along the fractures suggests some continued movement. (Figure 9).

The landslide scars continue around the dome to the south, interrupted by a large ridge where the main hiking path (Chemin des Muletiers) (Figure 5) ascends to the summit. In this ridged area, the dome lava is more massive and the marked down-slope foliation is more spaced and much steeper $\left(60-80^{\circ}\right)$. On this ridge, radial foliation and fractures dominate instead, along with breccia zones and fumarole-altered outcrops. This vertical foliation creates a serrated morphology. The top of this area flattens and is separated from the summit by a small scarp, which is tentatively interpreted as a slumped block (between sample sites PDD1 and PDD10 on Figure 5, and see Figure 6).

To the eastern side of the large ridge, a broad landslide scar occupies the southern flank (Figure 5), before the primary smooth eastern slope of the dome is regained to the south-east. The foliation is again concentric and down-slope within and on the edge of this scar, in addition to radial vertical fractures.

Below all the landslide scars, the terrain is rough and large blocks are mixed with a coarse angular breccia of Puy de Dôme lava. The uneven surface is very different from the smooth eastern slopes and the alluvial fans. Small ridges and scarps that strike down-slope along with the coarse breccias indicate that these are debris flow deposits (Figures 5 and 8). In some places the Puy 

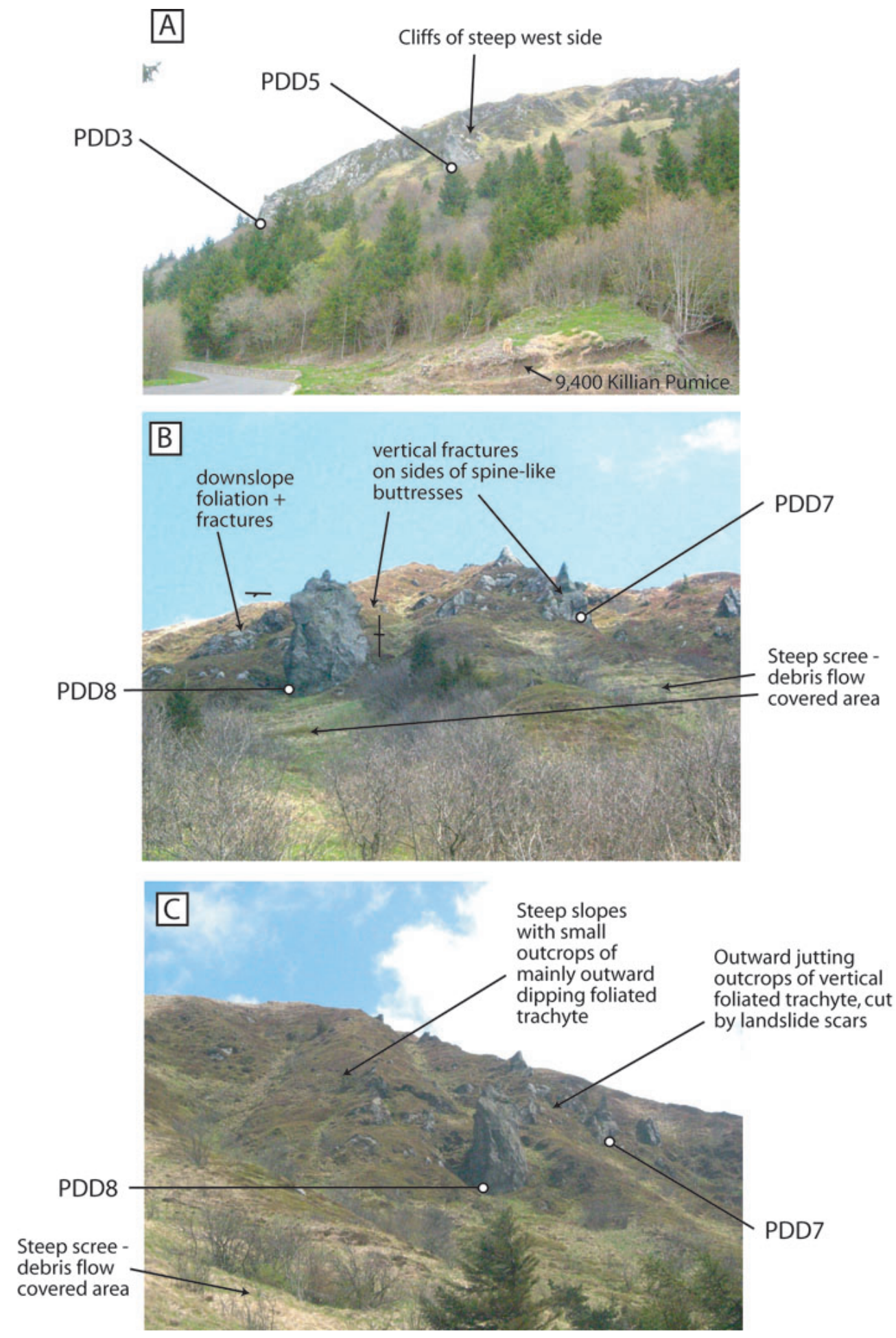

Figure 8: Pictures taken from the Puy de Dôme, of its slopes. [A] Looking over the old road (now train track) from the southwest side up to the west side and sample points PDD3 and PDD5. The former forms a large cliff buttress (Figure 8B) with fractures above and below the sampling site that retains a highly fractured downslope dipping plane. The outcrops above could be an arrested or potential landslide (see Figure 9 for close up images). [B] Sample sites PDD7 and PDD 8 on the west side of the steepest part. These have steeply outwardly dipping foliation, producing slabby outcrops. Vertical radial fractures are also seen, which guide the sides of deep landslide-controlled gullies. [C] Same sample sites as [B], but viewed from the northwest side. 
de Dôme material is covered or mixed with the pumice from the Kilian eruption, indicating that debris flows also occurred after this eruption.

Immediately to the north of the Puy de Dôme, the Petit Puy de Dôme is a prominent feature (Figures 2, 5 and 7). This is a deformed and uplifted scoria cone, with a probable trachytic intrusion below, that also caused a small phreatic eruption, the 'Nid de la Poule' [van Wyk de Vries et al. 2014]. Figure 5 shows the Petit Puy de Dôme and the faults that extend off its southern side, which are aligned with a deep gully on the Puy de Dôme and the scarps on the dome summit (views in Figure 7).

To the south-east of the Puy de Dôme, there is another intrusion-related uplift called the Grosmanaux (Figure 2), which hosts the Kilian vulcanian crater. The Kilian uplift is up to $100 \mathrm{~m}$, half that of the northeastern Petit Puy de Dôme bulge [van Wyk de Vries et al. 2014].

\subsection{Rock Magnetic Experiment Results}

Magnetic experiments on rock samples were conducted to determine the magnetic mineralogy and domain state of the principle magnetization carriers in the Puy de Dôme. The rock magnetic data indicate that the dominant magnetic mineral phase is a cubic Fe-Ti oxide of a restricted magnetic grain size, primarily pseudosingle domain titanomagnetite with a minor amount of coarse-grained maghemite and hematite. The detailed rock magnetic results are presented in Appendix 1.

\subsubsection{Curie Point Estimates}

The Curie Point estimates are indicative of a single magnetic phase for most samples of a low to moderate titanomagnetite composition [Dunlop and Özdemir 1997]. We do not see evidence of high coercivity phase(s). These data provide evidence that the samples contain a magnetic phase that is capable of preserving a geologically stable primary remanent magnetization.

\subsubsection{Isothermal Remanent Magnetization}

All Isothermal Remanent Magnetization (IRM) acquisition curves are steep and reach $\sim 85 \%$ saturation by $\sim 0.40 \mathrm{~T}$ with the remaining $15 \%$ of the magnetization acquired up to $2.5 \mathrm{~T}$. The results indicate the dominance of magnetite, likely single domain titanomagnetite of a restricted grain size, along with the presence of titanomaghemite and hematite [Özdemir and Dunlop 2003]. These data support the Curie point estimates in that the rocks contain a magnetic phase capable of preserving a geologically stable remanence.

\subsubsection{Low Temperature Remanence}

The magnetic properties measurement system (MPMS) results yield similar curves on warming yet the absolute intensity of the magnetization remanence varies between the three representative samples. All show a suppressed Verwey transition [Verwey 1939] indicative of non-stoichiometric behavior. Ti cation substitution or partial oxidation can lower the transition temperature or suppress it entirely [Özdemir et al. 1993]. We see evidence of a hematite Morin transition.

In summary, all the rock magnetic data indicate that the Puy de Dôme trachyte is a material that is capable of preserving a geologically stable remanence and there is no evidence of secondary magnetizations acquired after initial cooling. The remanence is likely to be a primary thermoremanent magnetization (TRM) that was acquired shortly after magma emplacement that formed the lava dome.

\subsection{Paleomagnetic Results}

\subsubsection{General Demagnetization Behavior}

Paleomagnetic data were obtained from seventeen sites across the Puy de Dôme (Figure 6). The seventeen sample sites yield overall normal polarity demagnetization results with a few specimens from some sites yielding reverse polarity directional data (Table 1; Figure 11). The overall progressive alternating field (AF) demagnetization response is characterized by a near linear trend to the origin for most samples defined over a broad range of peak fields. Most samples yield a single-component magnetization that decayed linearly to the origin with less than $10 \%$ of the natural remanent magnetization (NRM) remaining after treatment in $80-120 \mathrm{mT}$ applied field or, for high coercivity phases, treatment with thermal demagnetization up to $630^{\circ} \mathrm{C}$. A few samples contained additional low coercivity viscous remanent magnetization (VRM) components that were readily randomized by $20 \mathrm{mT}$ (Figure 11) with the remaining magnetization decaying along a linear trend to the origin.

Four sites did not yield stable end-point behaviour or had a high dispersion between specimens within the site (random normal and reverse polarity directions); these four sites were rejected and will not be discussed further. The thirteen accepted sites yield welldefined normal polarity magnetization directions that provided a group mean direction of $\mathrm{D}=19.7^{\circ}, \mathrm{I}=70.8^{\circ}$, $\alpha 95=4.4^{\circ}, k=90.1, \mathrm{n}=13$, which is statistically distinct at a $95 \%$ confidence level from the expected Quaternary normal polarity field direction $\left(\mathrm{D}=359.3^{\circ}, \mathrm{I}=\right.$ $64.2^{\circ}, \mathrm{A} 95=5.7^{\circ}$ ) based on the average data of multiple Quaternary virtual paleomagnetic pole positions (Table 2; Figure 12).

To test the dispersion of the site mean virtual geomagnetic poles (VGPs), we compared the average VGP 

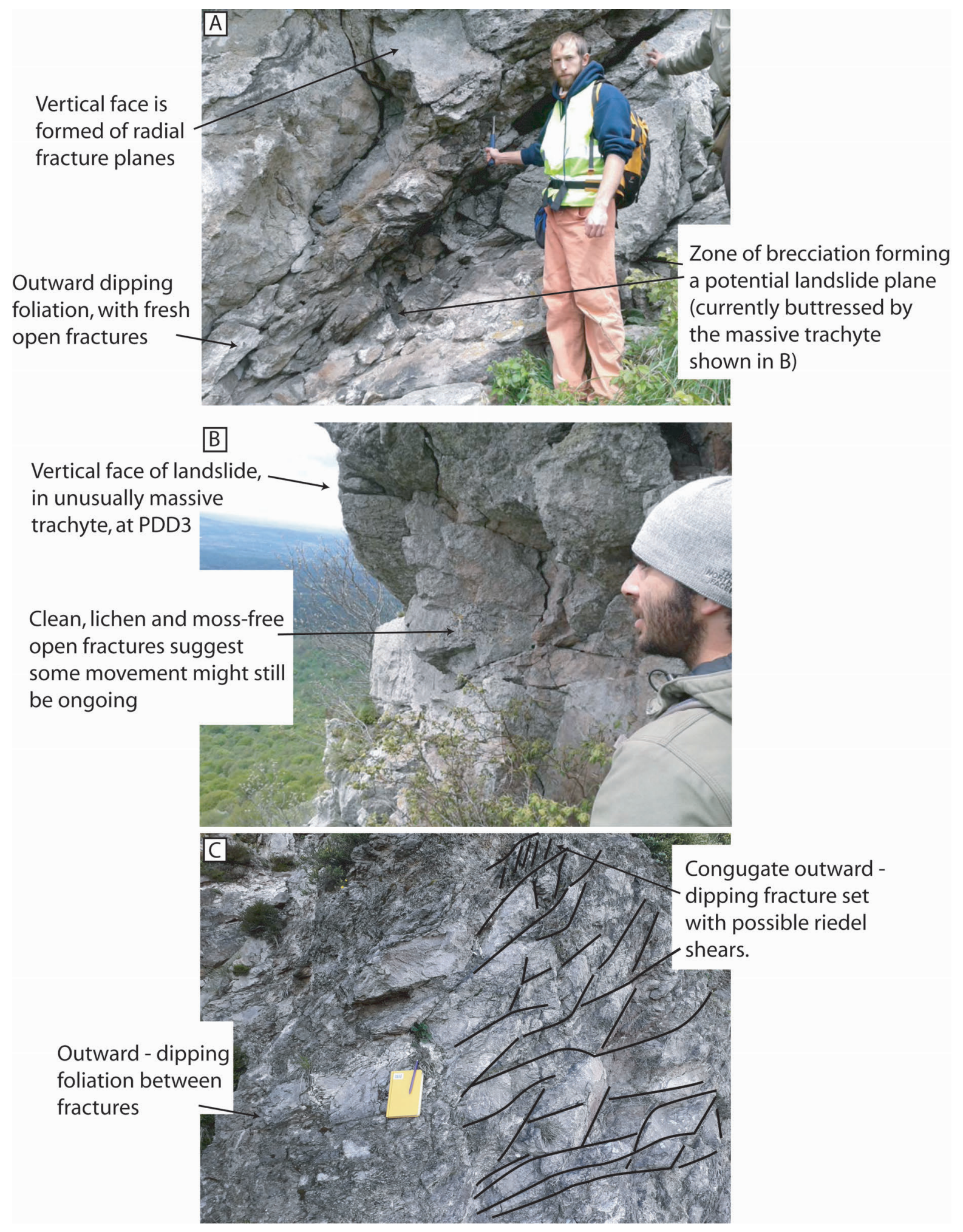

Figure 9: Pictures of the Puy de Dôme outcrops. [A] Fresh open fractures that are parallel to the magmatic foliation in the downslope-dipping breccia zone near sample site PDD5. [B] Massive buttress at PDD3, which is an unusually poorly foliated or fractured outcrop and which buttresses the potential landslide planes shown in [A]. This vertical face is probably the side wall of a landslide scar, which formed the elongate gully. The ope fractures are clean with no lichen, suggesting recent formation. [C] Outcrop of lava, $200 \mathrm{~m}$ down road on south side of Puy de Dôme. Here the trachyte lava shows the typical foliation, and outward-dipping conjugate fractures, with steeper planes as Riedel shears. While fractured, the outcrop is one coherent rock mass, suggesting that it deformed while still ductile and hot at low strain rates. 

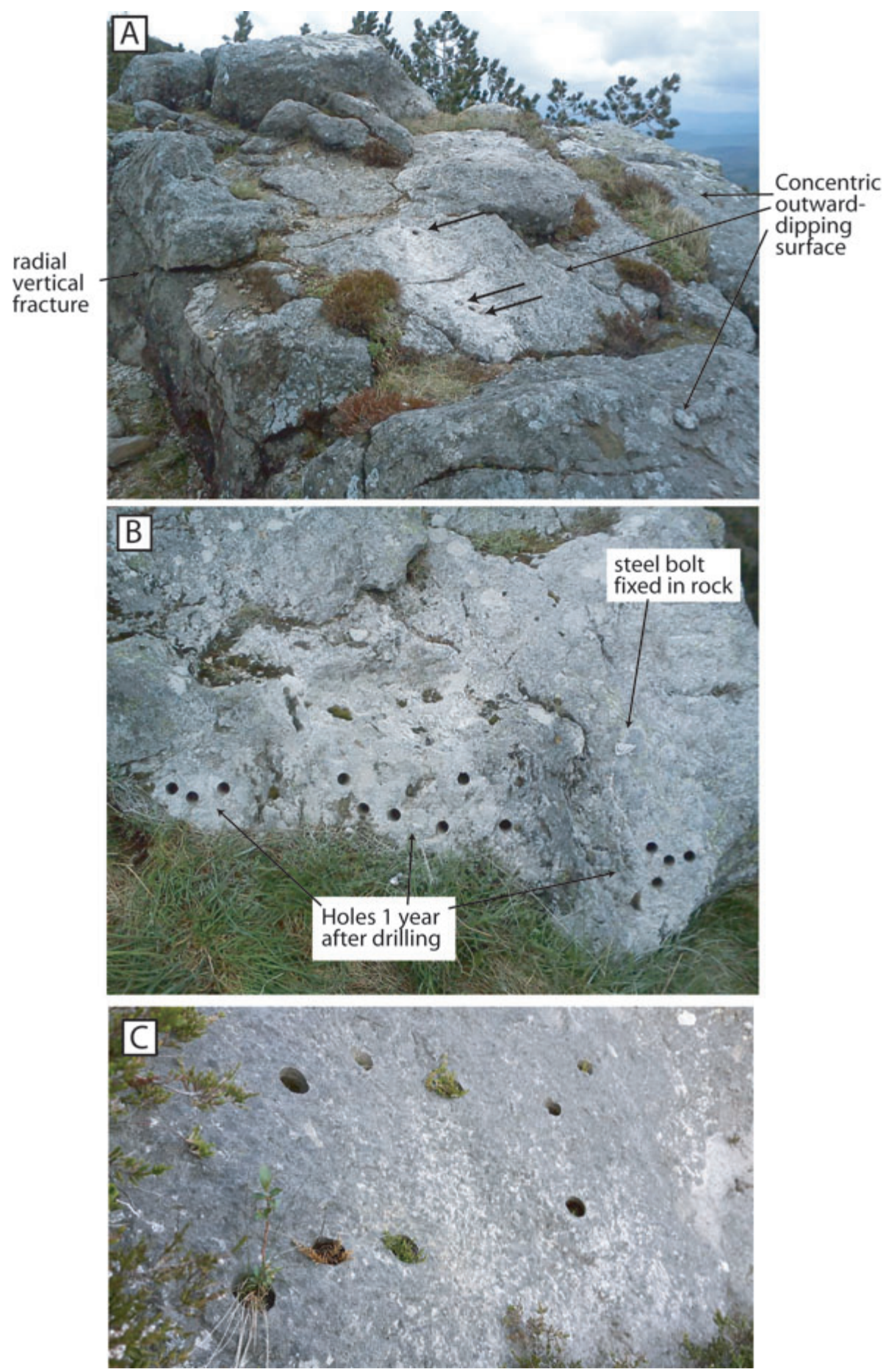

Figure 10: Pictures of sample sites showing how they are integrating back into the natural environment. All sites were chosen to be out of sight of the main tourist paths, in off-limits areas. The only exception is for a site near the restaurant terrace, where holes were drilled to be viewed by visitors. Holes were not filled-in, as they return to a 'natural' weathered state better with the least intervention. [A] Site PDD9, just below the summit of the Puy de Dôme on a scarp above a slight depression that might be a slumped block. [B] Site PDD1 on the very summit of the Puy de Dôme, next to the terrace on the café (note steel ring on rock). [C] Site PDD4 on the north side of the Chemin des Muletiers, the main walking path up the south-east of the Puy de Dôme.

dispersion to the predicated dispersion value for the latitude of the site $\left(45.5^{\circ} \mathrm{N}\right)$ [Merrill and McElhinny 1983]. If secular variation has been adequately sampled, the observed angular dispersion estimate of site mean VGPs should be consistent with that predicted. In this case $\sim 17.0^{\circ}$ with a \pm error range of $18.0^{\circ}$ to $15.5^{\circ}$ (Table 1; Merrill and McElhinny [1983]). The estimated dispersion $(S)$ of the thirteen accepted site mean direc- 

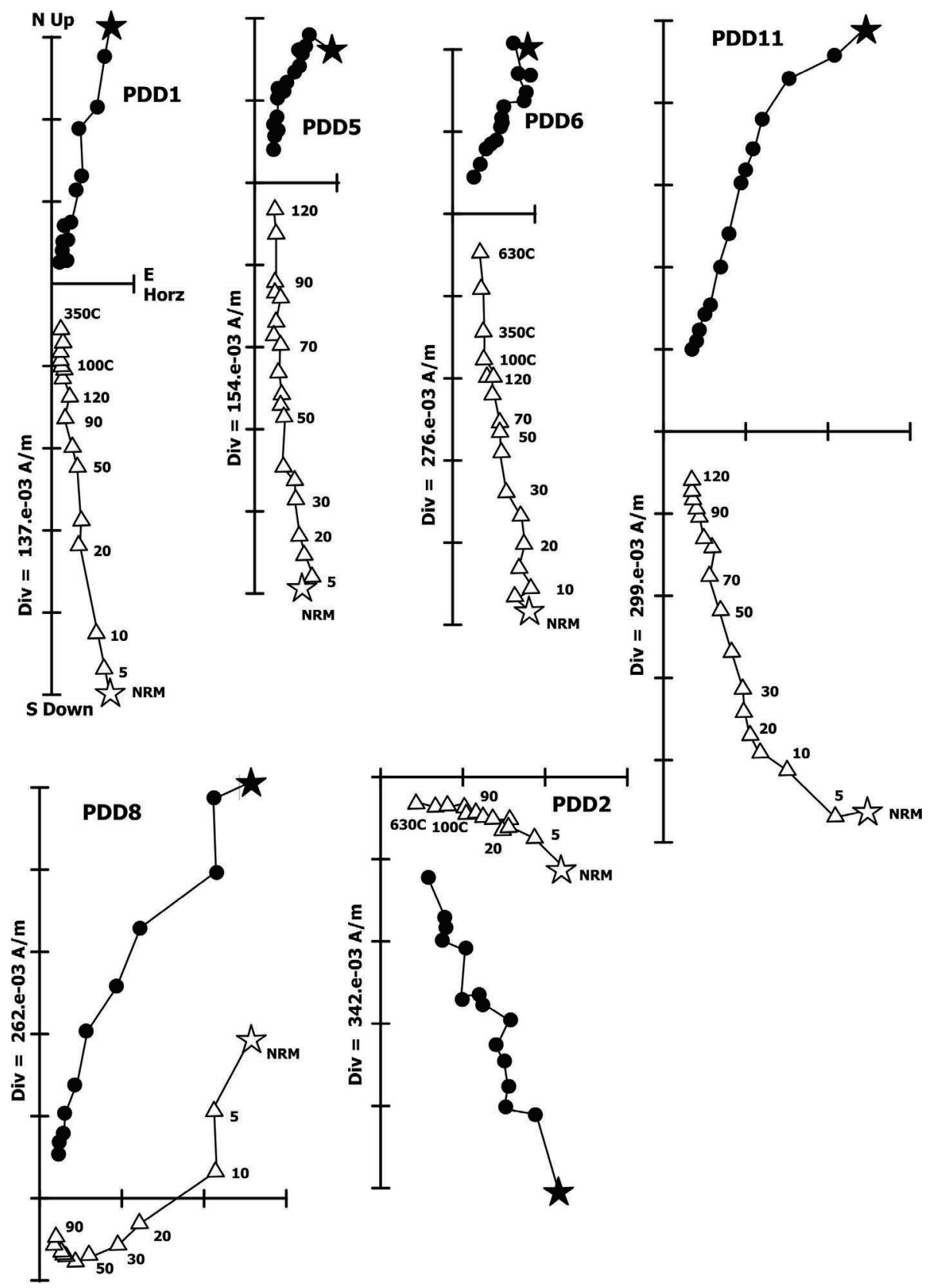

Figure 11: Orthogonal demagnetization diagrams representing the typical AF and TH demagnetization behavior [Zijderveld 1967]. Solid symbols represent the projection onto the horizontal plane, open symbols onto the vertical. The demagnetization steps are given in $\mathrm{mT}$ and temperature $\left(\mathrm{T}^{\circ} \mathrm{C}\right)$. Magnetization $(\mathrm{in} \mathrm{A} / \mathrm{m})$ is shown along one axis for each sample; each division equals indicated intensity. A few samples contained additional low coercivity viscous remanent magnetization (VRM) components that were readily randomized by $20 \mathrm{mT}$.

tions yields a group mean VGP dispersion of $13.3^{\circ} \pm$ $6.9^{\circ}$ (95\% confidence); a value which is less than, yet statistically indistinguishable from, the predicted VGP dispersion estimate. From this analysis, we suggest that the thirteen sites may reflect either 1) a time interval covering the longer periodicities of secular variation and represent a time averaged result, or 2) tectonic deformation associated with differential tilting of the dome. As we discuss below, we prefer the latter interpretation of the data given the field relationships.

\subsection{Anisotropy of Magnetic Susceptibility Results}

A1 summarizes all anisotropy of magnetic susceptibility data and key magnetic parameters. $K_{m}$ (mean bulk susceptibility) intensities (in the SI system) are moderate and range from $9.81 \times 10^{-3}$ SI to $0.24 \times 10^{-3}$ SI with a mean of $3.16 \times 10^{-3} \pm 2.53 \times 10^{-3}$ SI. The AMS fabric results reveal a near random orientation of $K_{1}$ lineation and $K_{1}-K_{2}$ foliation plane data; 16 of 17 susceptibility ellipsoid shapes are oblate (A1 A). The corrected degree of anisotropy ( $P j$; Jelinek [1981]) varies between 


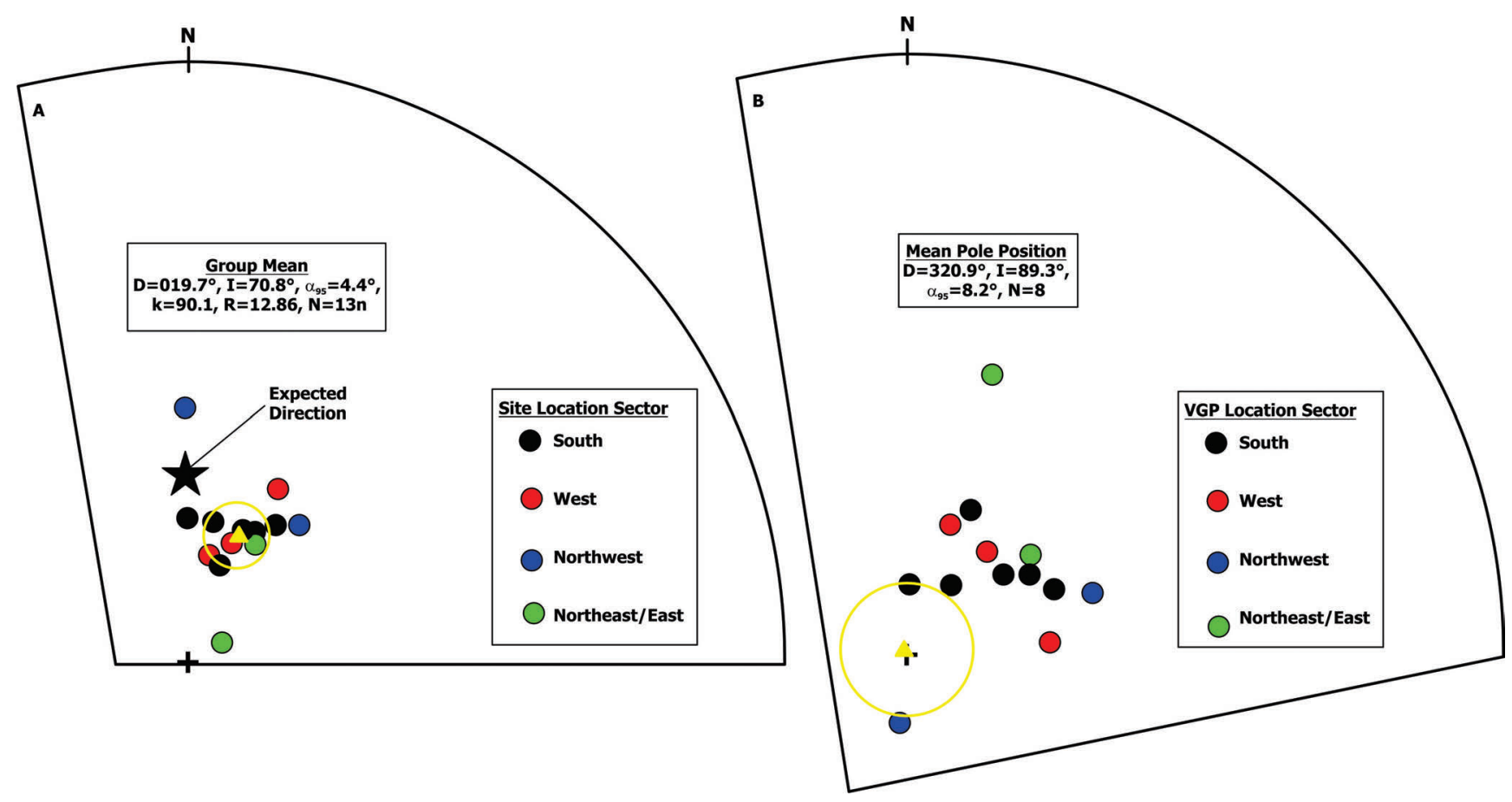

Figure 12: Paleomagnetic data from the Puy de Dôme. [A] Lower hemisphere equal area projection of site mean paleomagnetic data from the Puy de Dôme. The yellow triangle indicates the group mean result of the 13 accepted sites with $\alpha 95$ confidence ellipse about the group mean direction. The black star is the Quaternary reference direction based on the average of multiple paleomagnetic poles (Table 2). [B] Lower hemisphere equal area projection of site mean virtual geomagnetic pole positions (VGPs). The yellow triangle with A95 confidence ellipse indicates the mean Quaternary virtual geomagnetic pole position (Table 2).

1.011 and 1.164 , and averages $1.067 \pm 0.053$, indicating a weak $(\sim 6 \%)$ degree of anisotropy. The magnetic lineation $(L)$ and foliation $(F)$ averaged $1.014 \pm 0.015$ and $1.048 \pm 0.041$, respectively. There was no correlation between the corrected degree of anisotropy $(P j)$ and mean susceptibility $\left(K_{m}\right)$, and no correlation between the shape parameter $(T)$ and $K_{m}, P j$ versus $T$ $\left(K_{m}=\right.$ mean bulk susceptibility, $P j=$ corrected degree of anisotropy, $T=$ shape parameter).

\section{Discussion}

\subsection{Implications of the Paleomagnetic Data}

The paleomagnetic and existing geochronology data from the Puy de Dôme place magma emplacement during the normal-polarity Chron C1n (0.0 Ma-0.780 Ma) in the Holocene [Gradstein et al. 2012]. The group mean data are statistically distinguishable at $95 \%$ confidence level from the expected Quaternary normal polarity field direction (Table 2 ) and yield a rotation $(R)$ and flattening $(F)$ estimate of $R=20.4^{\circ} \pm 12.5^{\circ}$ and $F=$ $-6.6^{\circ} \pm 7.5^{\circ}$ relative to the expected field direction (Table 1).

These paleomagnetic data can be interpreted as being either a time-averaged result, a spot reading of the geomagnetic field, or a time-averaged result with the di- rectional discordance attributed to deformation of the dome. The dispersion of the VGPs is less than the predicted value of $\sim 17^{\circ}$, but there is statistical overlap. Here, we argue that the paleomagnetic data likely do not represent a time average result and the spatially variable directional data reflects tectonic deformation that has led to the discordance of the data relative to the expected field direction.

In order to evaluate the paleomagnetic data more fully to assess any possible variation in age or true dispersion among the data, a mean discrimination test was conducted between each individual site mean [McFadden and Lowes 1981]. Essentially, the test compares an observed site mean direction to another observed site mean direction with the null hypothesis being that the two mean directions are separate samples from the same population of directions and the same geomagnetic field direction.

Alternatively, if the means are distinct, they were either drawn from different populations that sampled different geomagnetic field directions or sub-volcanic deformation occurred which increased the dispersion of the data between sampling locations. The mean discrimination test does not prove the null hypothesis, but sets a probability (in this study $95 \%$ ) of it either being accepted or rejected. The mean discrimination test results reveal that seven sites are statistically distinguishable at the $>95 \%$ confidence level from the other six 
Table 1 - Paleomagnetic data from the Puy de Dôme, Auvergne, France. Explanation: Site, site name; N/No, number of specimens means used in site mean $(\mathrm{N})$ to total number of specimen means at the section (No); Dec/Inc, site declination and inclination; R, resultant vector length; $k$, best estimate of (Fisher) precision parameter; $\alpha 95,95 \%$ confidence interval of the estimated site mean direction assuming a circular distribution; VGP Lat/Long, latitude and longitude of the virtual geomagnetic pole; Rotation $(R)$ and flattening $(F)$ and associated error estimates $( \pm R, \pm F)$ [Beck 1980; Demarest 1983] with respect to the average Quaternary expected field direction.

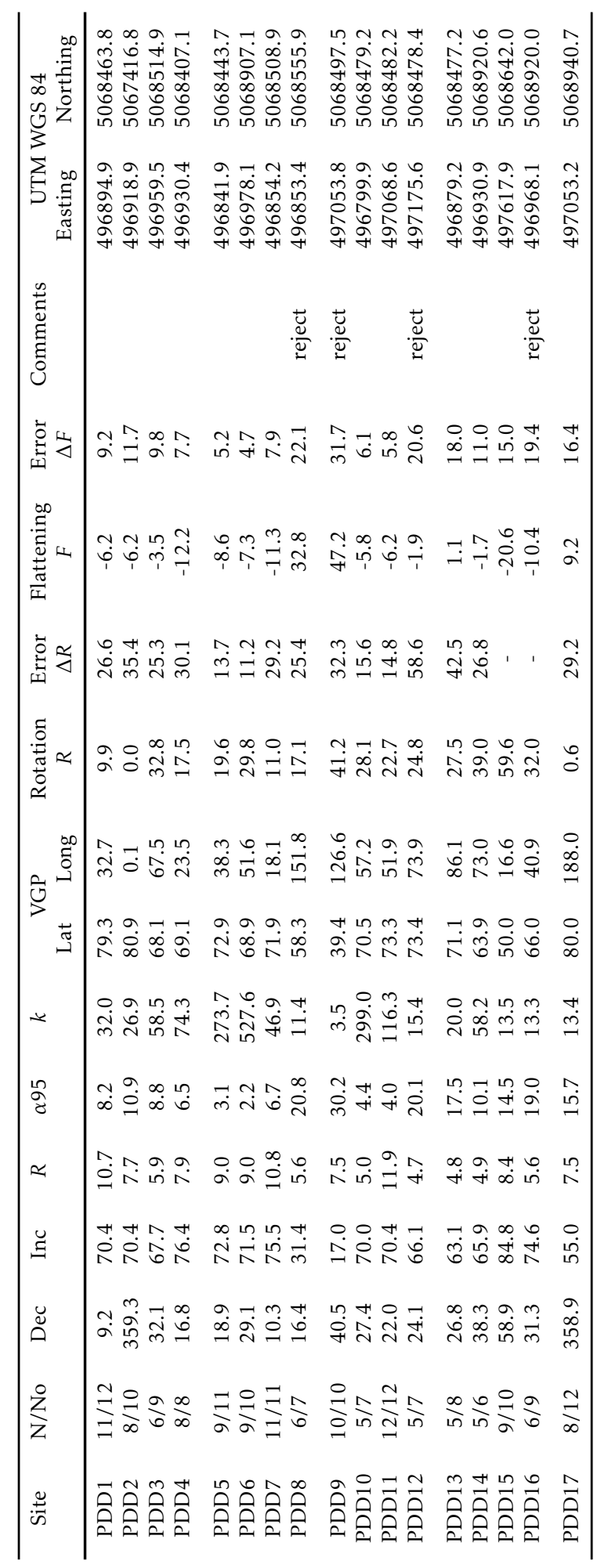

Table 2 - Quaternary virtual paleomagnetic pole positions and calculated expected directions for the Puy de Dôme. Explanation: Rock Name; Age, estimated age in millions of years (Ma) or thousands of years (Ka); VGP Position, virtual geomagnetic pole position; Expected Direction, based on the cited references; A95 (estimated), error estimate of the calculated pole position.

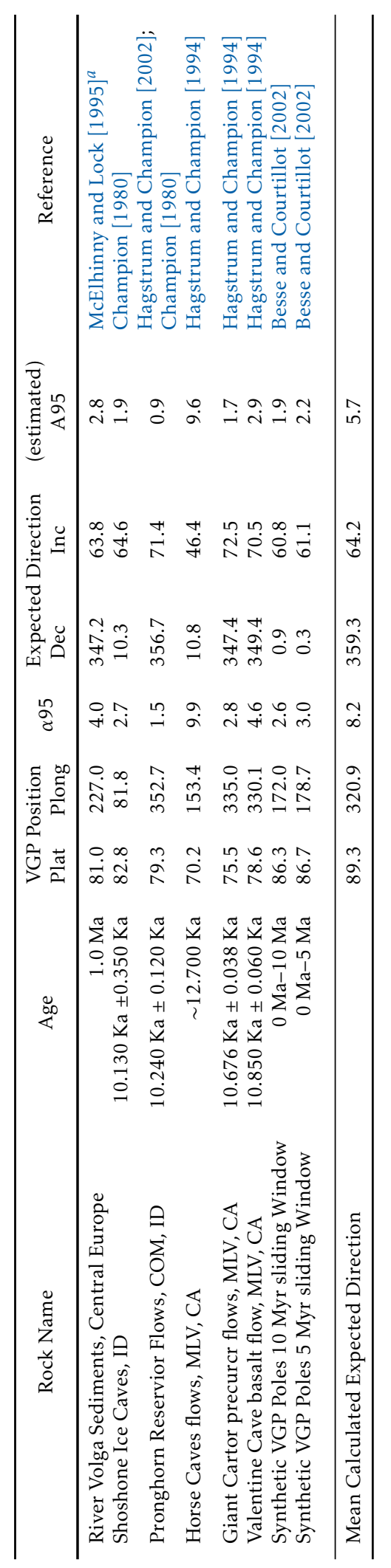

${ }^{a}$ extracted from the Global Paleomagnetic Database. 
accepted sites (Table 1). The remaining sites are statistically indistinguishable from each other at $>95 \%$ confidence.

We interpret the statistically distinct sites to reflect some post-emplacement deformation following remanence acquisition. The pattern of deformation across the dome reveals that the tilting (i.e. rotation) is, for the most part, uniform with only local deformation between a few site locations. We suggest that the subvolcanic deformation from the Petit Puy de Dôme may have caused the observed discordance of the paleomagnetic data following remanence acquisition.

\subsection{Emplacement and Deformation Mechanism of the Puy de Dôme}

The geomorphological, structural and paleomagnetic data all indicate that the Puy de Dôme has been tilted to the south-east some time after it erupted and cooled. The paleomagnetic data also suggest that the dome extruded as one unit and solidified without any major reorientation of the cooled carapace. This makes the Puy de Dôme a monogenetic dome with one short-lived eruption, but the tilting and activity of the Petit Puy de Dôme began before, and continued after the simple dome extrusion (Figures 13 and 14). We note that there was probably a deflation phase of the Petit Puy de Dôme during the effusion of the dome (Figure 14), although no clear evidence has been left of this.

Subsequent to dome emplacement there was another eruption from the summit, a few hundred years after the cessation of the first (a thin soil layer is present between the two deposits [Miallier et al. 2010]). A thousand years after this, the Kilian erupted and its products were deposited over the Puy de Dôme, and during this interval two small trachyandesite eruptions (Nid de la Poule and possibly the Traversin) occurred, as well as the trachyte-basalt Puy de Pariou eruption just to the north-east [Miallier et al. 2012]. Kilian tephra deposits are found on the Petit Puy de Dôme [Miallier et al. 2012], so the deformation associated with the latter, and thus the tilting, could extend to around the eruption of the second Puy de Dôme tephra. Since the Petit Puy de Dôme is considered to have triggered the eruptive sequence by growing and then breaching to the south-west to allow the extrusion of the Puy de Dôme, this bulge growth both pre-dates and post-dates the Puy de Dôme.

The sequence is thus: Petit Puy de Dôme bulging > Puy de Dôme lava extrusion $>$ ongoing growth of Petit Puy de Dôme + final Puy de Dôme small eruption > Nid de la Poule eruption (+ more bulging?) > Kilian eruption.

If we draw comparisons with current volcanic activity, the Puy de Dôme-Petit Puy de Dôme growth could be seen as an equivalent of the Usu volcano domes [Minakami et al. 1951; Katsui et al. 1985; Tobita et al. 2001], which grew in a matter of weeks to months.
The long term growth of the Petit Puy de Dome could be equated to the continually deforming Alu bulge in Ethiopia [Magee et al. 2017; Pagli et al. 2012].

Thus both eruption and tilting of the Puy de Dôme probably happened over weeks to months, while the intrusion growth took maybe a few hundred years, possibly extending to the Nid de la Poule eruption with a more mafic magma input. There may have been inflation and deflation periods, the latter associated with the eruptions.

The petrographic and intrusive sequence of events can be seen as a prolonged monogenetic eruption, during a heightened period of activity in the Chaîne des Puys, which verged on polygenetic in its duration and complexity.

The Puy de Dôme is not the only volcano in the Chaîne des Puys to have been affected by subsequent, geographically-close eruptions. For example, the Grand Suchet is tilted to the west by the Puy Suchet trachyte intrusion [van Wyk de Vries et al. 2014]. Also, the Chopine trachyte intrusion deformed the Puy de Gouttes before destroying the latter in a sector collapse [van Wyk de Vries et al. 2014]. Other cones, such as the Montchie and Lemptégy have had multiple eruptions [Petronis et al. 2013; Miallier et al. 2013], separated by long time-periods during which the edifices have completely cooled. An extended sequence is also seen with the Pariou eruption and that of the Puy de la Nugère [Camus et al. 1995; Boivin et al. 2017], that go from initial trachyte to basalt.

The response of each cone to the subsequent intrusion/eruption varies. In general they all are deformed and tilted, and may additionally be pierced by eruptions and/or suffer landslides. The Puy de Dôme itself has been tilted, pierced by a small eruption and has undergone a landslide on the south-west side. The reason that there was not a larger collapse, such as that of the Gouttes, might relate to the strength and structure of the Puy de Dôme trachyte, which ensured that the core remained intact while only some of its outer carapace was shed on the outward-dipping planes.

As many cones in the Chaîne des Puys have been affected by subsequent tilting, such activity might be related to the dense concentration of edifices; the Chaîne has the highest concentration of any monogenetic field [Corvec et al. 2013]. Such interference between edifices would be less likely in more dispersed monogenetic fields. On stratovolcanoes, pulses of magma intrusion follow one after another, and so similar tilting could occur. However, the magma volume may be small with respect to the volume of the edifice, creating a partial bulge rather than tilting, such as at Mount Saint Helens or Bezymianny [van Wyk de Vries et al. 2014]. Larger intrusions might occur, but the likelihood of magma breaking out at the surface might limit the scale of uplift and tilting, instead giving rise to the formation of a satellite cone. Also, the larger size of a stratovolcano with respect to its internal strength would favour de- 

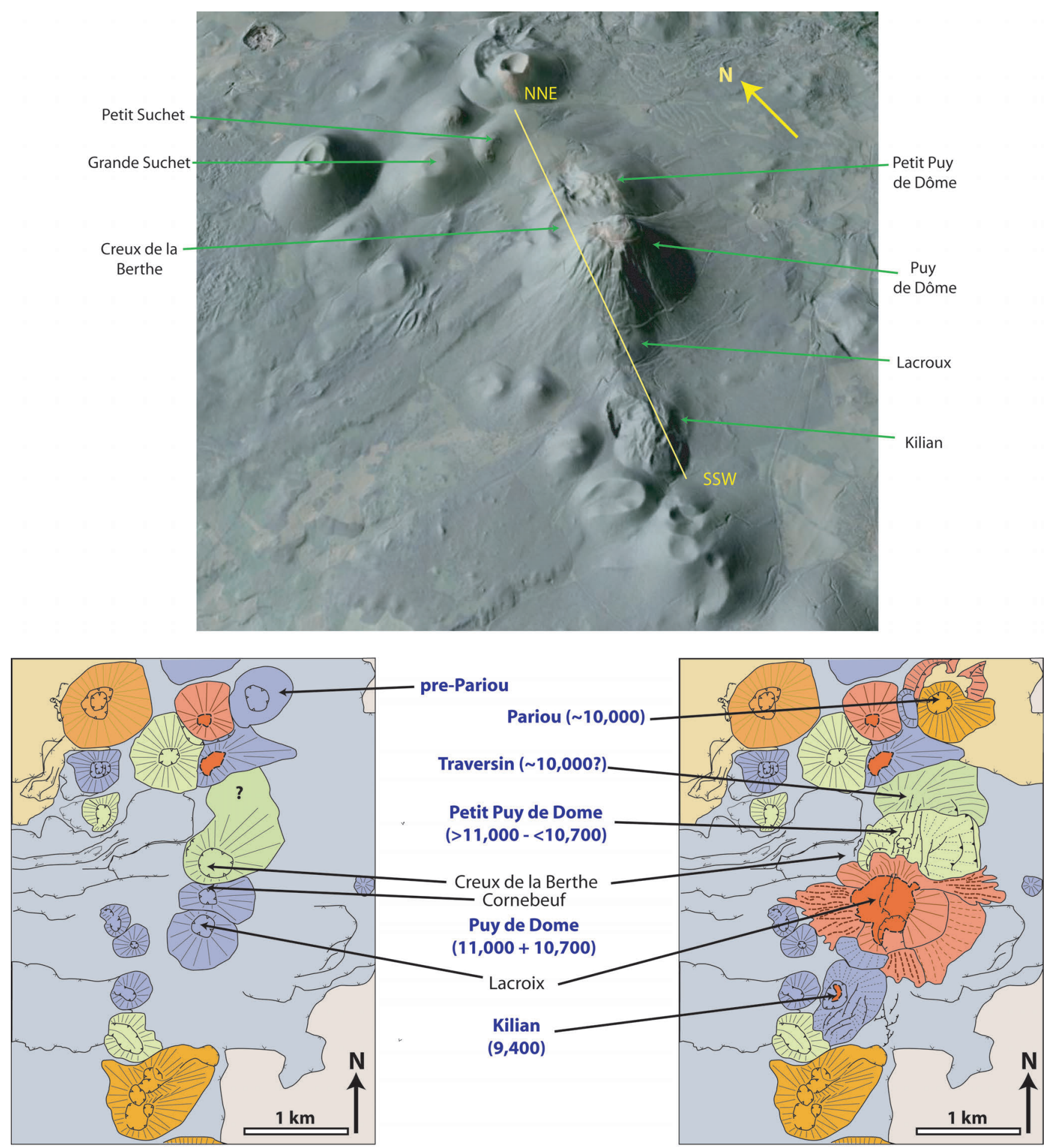

before 11,000 years

after 9,400 years

Figure 13: History of the Puy de Dôme area. [A] Oblique image of LiDAR-derived shaded relief (CRAIG dataset), overlain on the Google Earth image of the Puy de Dôme area. Line of cross section in Figure 14 shown in yellow. [B] Map of the area up to 10,000 years before the start of the Petit Puy de Dôme intrusion. [C] Map after 9,400 years (e.g. like in Figure 2), with the newly appeared volcanoes and structures indicated. Compare this diagram with the cross-sections in Figure 14.

formation of a relatively smaller area. Thus tilting of an entire, large stratovolcano seems unlikely, at least by shallow intrusions, but growth of larger magma chambers at greater depths could provide the volume and area of uplift to tilt a large volcano. The large-scale sliding of the Mull volcano [Mathieu and van Wyk de Vries 2009], or the present-day Mount Etna could be considered in this context [Borgia et al. 1992]. The huge 
A. before 11,000 years

Creux de la Berte, and Cornebeuf scoria cones

Aumone dome and Traversin

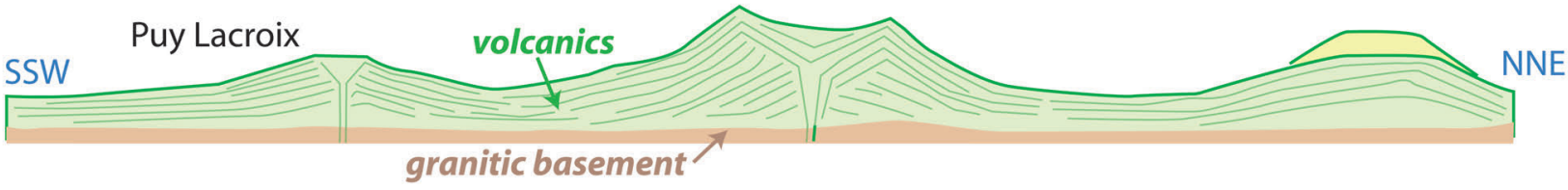

B. near 11,000 years

Petit Puy de Dôme bulge begins
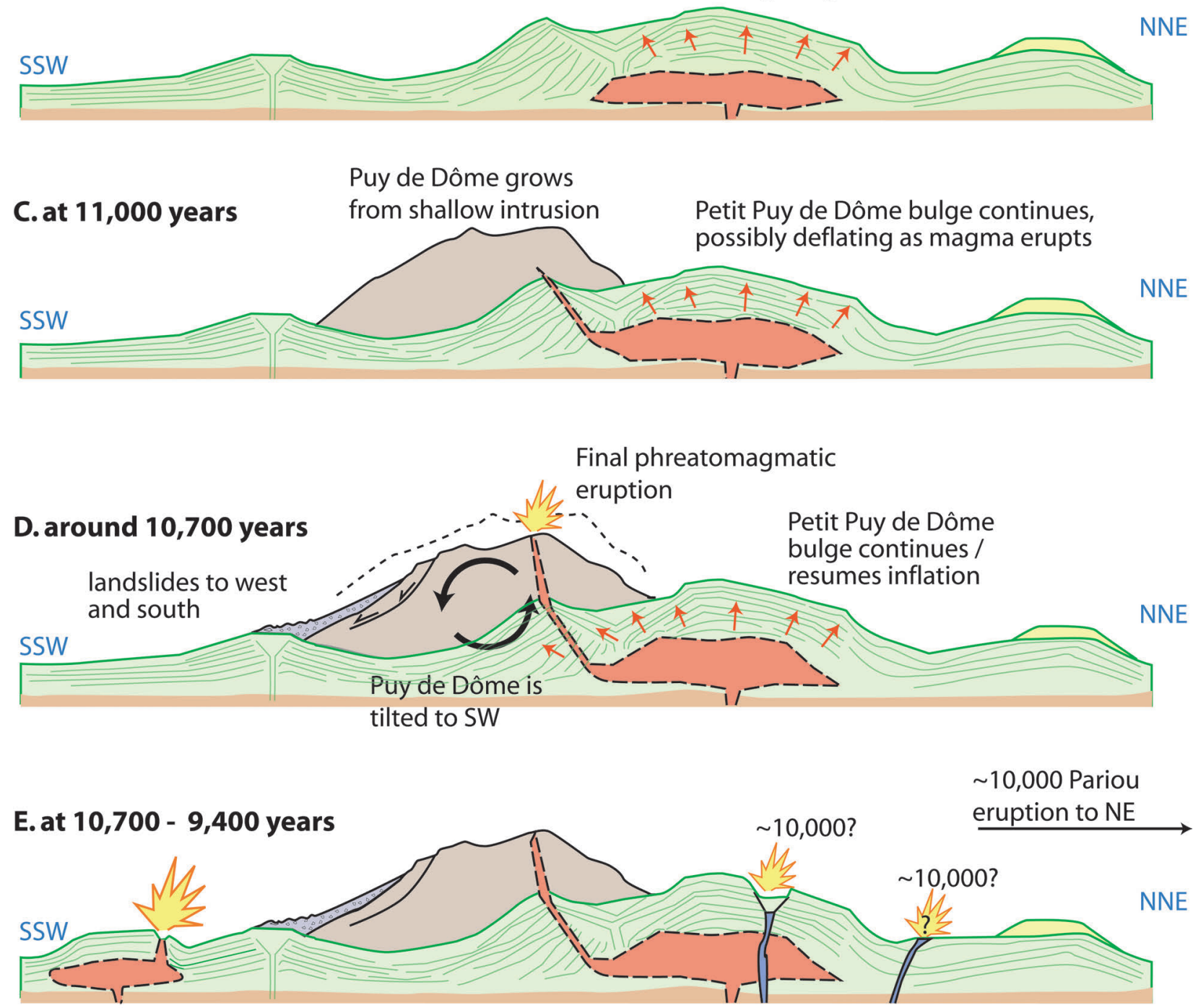

Kilian bulge forms and erupts at 9,400

Nid de Poule and Traversin eruptions at end of bulging befor Kilian

Figure 14: Summary cartoon of the sequence of events around the Puy de Dôme. [A] Pre-Puy de Dôme before 11,000 years BP. The area is mostly older scoria cones, with one trachyte dome, the Petit Suchet, emplaced a few thousand years before. [B] Start of activity with shallow intrusion starting to create the Petit Puy de Dôme bulge. [C] Trachytic magma breaks through on the south of the bulge to allow the Puy de Dôme to grow. We note that there was probably a deflation phase of the Petit Puy de Dôme during the effusion of the dome, although no clear evidence has been left of this. The dome gains a carapace of ash towards the end [Boivin et al. 2017]. [D] The cooled Puy de Dôme is then tilted by continued growth of the Petit Puy de Dôme, and a small summit eruption occurs around 10,700 BP. [E] Activity stops, and a small trachyandesitic eruption cuts the Petit Puy de Dôme (Nid de la Poule) and possibly a small vent opens on the Traversin. This activity may have occurred at about 10,000 years with the Pariou eruption. Then at 9,400 BP the whole area is covered by Kilian eruption deposits. 
uplift and sliding identified at Heart Mountain, Utah, USA [Beutner and Gerbi 2005] shows that such grandscale tilting is possible. So finally, while it appears most likely that tilting is more common on small, monogenetic volcanoes, especially lava domes, the same processes can occur in a scaled up way in larger systems.

The message for monitoring and hazards is that broad uplift beneath one side of a volcano might be accompanied by a collapse of the opposite side, in the direction possibly least expected.

The paired collapses on opposite flanks of Mombacho, Nicaragua, might be an example of this [Shea et al. 2007], where intrusion and alteration of a bulge on the SE side caused a landslide on the south side, as well as generating a corresponding slide on the north side of the volcano. Therefore, when volcanoes start to deform due to an intrusion, a whole range of possible scenarios need to be considered. It is only as the growth of such a bulge evolves that the outcome might become clear.

\subsection{Geoheritage and conservation}

This work adds to the growing body of knowledge about the history of the iconic Puy de Dôme, contributing to the understanding of an important part of the Chaîne des Puys - Limagne Fault World Heritage site. The work also supplies information that can be integrated into the conservation strategy for the site, especially identifying key outcrops, key natural areas and locations of high geoheritage value. These can be integrated into a detailed geosite inventory, which is as yet to be created for the site, but without which it can not be properly protected [van Wyk de Vries and Vereb 2019].

The geomorphological mapping helps identify how the dome evolved during and after eruption, especially the erosional processes that accompanied and followed tilting and which are ongoing at present (slope creep, landslides, rock fall, debris flows). The mapping helps underline that the Puy de Dôme remains an activelyevolving landscape feature. The areas of the dome where these active natural surfaces processes are little or unaffected by anthropic activity have become better known. This increases the potential to protect these by providing vital information to indicate to authorities where human intervention should be avoided. It also gives scientists experience of the site that can be used to advise on the management of anthropic installations (e.g. cog train and paths), so that they can have the least effect on the natural environment.

This improved knowledge is not yet fully formalised and integrated into the conservation strategies for the Puy de Dôme, exposing it to a risk of damage to its outstanding geoheritage.

We are presently urgently talking to and working with the World Heritage site managers to rapidly integrate the new information, and to formalise a detailed inventory, since development projects, such as slope stabilisation are already planned to start (14 October 2019) that have not yet benefited from any in-depth geoheritage constraint.

\section{Conclusions}

Geomorphological mapping has showed that the Puy de Dôme is asymmetric and steeper to the south-west than the north-east. Paleomagnetic data are consistent with a modest tilt of the dome on a north-west axis. The tilt is best explained by the 200 meters of uplift produced on the north-east side by the Petit Puy de Dôme bulge. The low dispersion of the paleomagnetic data from the Puy de Dôme also suggests that the dome cooled essentially en-masse without significant post eruption flow.

Whole scale tilting of volcanic edifices by intrusions may have occurred at other volcanoes in the Chaîne des Puys and elsewhere. At larger scales this could affect the stability of large stratovolcanoes.

Precursory activity, in terms of doming and faulting at the base of the edifice could provide timely warning of the way intrusions are developing. Such activity is especially likely to occur at previously dormant volcanoes that have consolidated their conduits. Deformation on one side might cause landslides on the other side, where they might not be expected. Hazard assessment should take this into account in the event of an intrusion being detected, as the opposite side from the most obvious danger may be at risk.

The tell-tale signs should be seen in tilting of the edifice away from a peripheral uplift, displacing the whole volcano to one side. Fracturing and precursory sliding on the opposite side of a bulge could also be a precursor to greater instability.

\section{ACKnowledgements}

This work was funded by New Mexico Highlands University Faculty Research funds, National Geographic Grant \#8887-11 awarded to Petronis and Lindline, National Science Foundation Grant \#1423396 awarded to Petronis and Lindline, and National Science Foundation Grant DMR-1523611 (PREM) awarded to Tatiana Timofeeva.. A special thanks to Dr. Linda LaGrange for her support of faculty and student research at New Mexico Highlands University.

A very special thank you to F. van Wyk de Vries for editing the manuscript. Tatum Miko Herrero, Giachino Roberti, Delphine Sourisseau assisted with the field sampling. Thanks also to Didier Miallier and Pierre Boivin for comments. Permission of sampling came from the Grande Site du Puy de Dôme, the Conseil Departmental du Puy de Dôme and the Train du Puy de Dôme as well as the commune of Ceyssat.

The final work has been carried out under the UNESCO Geosciences Project No 692 'Geoheritage for Geohazard Resilience'. 


\section{Author COnTRibutions}

This work represents a large portion of Garza's Master's thesis research at New Mexico Highlands University, supervised by Petronis and van Wyk de Vries. Both Petronis and van Wyk de Vries were primarily responsible for the initial ideas and plans, and then writing the manuscript, drafting the figures, and data interpretation. All authors worked to collect the data, and Garcia ran the palaeomagnetic analyses under supervision of Petronis.

\section{Data AVAilability}

All data related to this project is available at http://www.nmhugeology.com/, the paleomagnetic data can be found in the MagIC database (https://www2.earthref.org/MagIC), and all data sets may be requested from the first author (mspetro@nmhu.edu).

\section{Copyright NOTICE}

(C) The Author(s) 2019. This article is distributed under the terms of the Creative Commons Attribution 4.0 International License, which permits unrestricted use, distribution, and reproduction in any medium, provided you give appropriate credit to the original author(s) and the source, provide a link to the Creative Commons license, and indicate if changes were made.

\section{REFERENCES}

Beck, M. E. (1980). "Paleomagnetic record of platemargin tectonic processes along the western edge of North America". Journal of Geophysical Research 85.B12, p. 7115. DoI: 10. 1029/ jb085ib12p07115.

Besse, J. and V. Courtillot (2002). "Apparent and true polar wander and the geometry of the geomagnetic field over the last 200 Myr". Journal of Geophysical Research: Solid Earth 107.B11, EPM 6-1-EPM 6-31. DOI: $10.1029 / 2000$ jb000050.

Beutner, E. C. and G. P. Gerbi (2005). "Catastrophic emplacement of the Heart Mountain block slide, Wyoming and Montana, USA". Geological Society of America Bulletin 117.5, p. 724. DoI: 10.1130 /b25451. 1.

Boivin, P., J.-C. Besson, D. Briot, C. Deniel, A. Gourgaud, P. Labazuy, E. Langlois, F.-D. De Larouzière, M. Livet, C. Merciecca, et al. (2017). Volcanologie de la Chaine des Puys Massif Central Français. Parc naturel régional des Volcans d'Auvergne.

Borgia, A., L. Ferrari, and G. Pasquarè (1992). "Importance of gravitational spreading in the tectonic and volcanic evolution of Mount Etna". Nature 357.6375, pp. 231-235. DoI: 10.1038/357231a0.
Boudon, G., H. Balcone-Boissard, B. Villemant, and D. J. Morgan (2015). "What factors control superficial lava dome explosivity?" Scientific Reports 5.1. DOI: 10.1038 / srep 14551.

Calder, E. S., Y. Lavallée, J. E. Kendrick, and M. Bernstein (2015). "Lava Dome Eruptions". The Encyclopedia of Volcanoes. Ed. by H. Sigurdsson, B. Hougton, S. McNutt, H. Rymer, and J. Stix. Elsevier, pp. 343-362. DOI: 10 . 1016/b978-0-12-385938-9.00018-3.

Camus, G. (1975). "La Chaine des Puys (Massif Central Français): Étude structurale et volcanologique, these, 319 pp". PhD thesis. Universite de ClermontFerrand, Clermont, France.

Camus, G., A. de Goër de Hervé, G. Keiffer, J. Mergoil, and P. Vincent (1995). Volcanologie de la Chaîne des Puys [Document cartographique] : Massif Central Français. [2nd edition].

Cârloganu, C. et al. (2013). "Towards a muon radiography of the Puy de Dôme”. Geoscientific Instrumentation, Methods and Data Systems 2.1, pp. 55-60. Dor: 10.5194/gi-2-55-2013.

Carrasco-Núñez, G. and N. Riggs (2008). "Polygenetic nature of a rhyolitic dome and implications for hazard assessment: Cerro Pizarro volcano, Mexico". Journal of Volcanology and Geothermal Research 171.3-4, pp. 307-315. Dor: 10 . $1016 /$ j . jvolgeores . 2007. 12.002.

Chadima, M. and F. Hrouda (2006). "Remasoft 3.0 a user-friendly paleomagnetic data browser and analyzer". Travaux Géophysiques. Vol. 27, pp. 20-21.

Champion, D. E. (1980). "Holocene geomagnetic secular variation in the western United States : implications for the global geomagnetic field". PhD thesis. California, USA: California Institute of Technology.

Colombier, M., L. Gurioli, T. H. Druitt, T. Shea, P. Boivin, D. Miallier, and N. Cluzel (2017). "Textural evolution of magma during the 9.4-ka trachytic explosive eruption at Kilian Volcano, Chaine des Puys, France". Bulletin of Volcanology 79.2. Dor: 10 . 1007 / s00445-017-1099-7.

Condomines, M. (1997). "Dating recent volcanic rocks through 230Th-238U disequilibrium in accessory minerals: Example of the Puy de Dôme (French Massif Central)”. Geology 25.4, p. 375. DoI: $10.1130 /$ 0091-7613 (1997) 025<0375: drvrtt>2.3.co;2.

Corvec, N. L., K. B. Spörli, J. Rowland, and J. Lindsay (2013). "Spatial distribution and alignments of volcanic centers: Clues to the formation of monogenetic volcanic fields". Earth-Science Reviews 124, pp. 96114. Dor: 10.1016/ j . earscirev.2013.05.005.

Cosgrove, J. W. and R. D. Hillier (1999). "Forced-fold development within Tertiary sediments of the Alba Field, UKCS: evidence of differential compaction and post-depositional sandstone remobilization". Geological Society, London, Special Publications 169.1, pp. 61-71. DoI: 10.1144/gsl.sp.2000.169.01.05.

de Wever, P., G. Egoroff, and S. Charbonnier (2015). "Le patrimoine géologique en France". La Lettre de l'OCIM 165, pp. 32-34. DoI: 10.4000/ocim. 1661. 
Demarest, H. H. (1983). "Error analysis for the determination of tectonic rotation from paleomagnetic data". Journal of Geophysical Research: Solid Earth 88.B5, pp. 4321-4328. DOI: 10.1029 / jb088ib05p04321.

Duffield, W. A., D. H. Richter, and S. S. Priest (1995). Physical volcanology of silicic lava domes as exemplified by the Taylor Creek Rhyolite, Catron and Sierra Counties, New Mexico. Tech. rep. 1. U.S. Geological Survey. [To accompany map I-2399].

Dunlop, D. J. and Ö. Özdemir (1997). Rock magnetism: fundamentals and frontiers. Cambridge University Press, New York, London, and Cambridge.

Faïn, J., D. Miallier, M. Montret, and S. Sanzelle (1988). "Zircon dating: Regeneration and evaluation of the external dose". International Journal of Radiation Applications and Instrumentation. Part D. Nuclear Tracks and Radiation Measurements 14.1-2, pp. 333-337. DoI: 10. 1016/1359-0189 ( 88 )90085-4.

France, L., M. Demacon, A. A. Gurenko, and D. Briot (2016). "Oxygen isotopes reveal crustal contamination and a large, still partially molten magma chamber in Chaine des Puys (French Massif Central)". Lithos 260, pp. 328-338. Dor: 10 . $1016 /$ j . lithos . 2016.05 .013$.

Gorshkov, G. S. (1959). "Gigantic eruption of the volcano bezymianny". Bulletin Volcanologique 20.1, pp. 77-109. Dor: 10.1007/bf02596572.

Gradstein, F., J. Ogg, M. Schmitz, and G. Ogg, eds. (2012). Elsevier.

Guettard, J. E. (1752). Mémoire sur quelques montagnes de la France qui ont été des volcans. l'Académie royale des Sciences, France.

Hagstrum, J. T. and D. E. Champion (1994). "Paleomagnetic correlation of Late Quaternary lava flows in the lower east rift zone of Kilauea Volcano, Hawaii". Journal of Geophysical Research: Solid Earth 99.B11, pp. 21679-21690. DoI: 10.1029/94 jb01852.

- (2002). "A Holocene paleosecular variation record from14C-dated volcanic rocks in western North America". Journal of Geophysical Research: Solid Earth 107.B1, EPM 8-1-EPM 8-14. Dor: 10 . 1029 / 2001 jb000524.

Jelinek, V. (1981). "Characterization of the magnetic fabric of rocks". Tectonophysics 79.3-4, T63-T67. DoI: 10.1016/0040-1951(81)90110-4.

Jerram, D., A. Scarth, and J.-C. Tanguy (2017). Volcanoes of Europe. Dunedin Academic Press Ltd.

Juvigné, E. and M. Gewelt (1987). "La Narse d'Ampoix comme téphrostratotype dans la Chaine des Puys méridionale (France)". Bulletin de l'Association française pour l'étude du quaternaire 24.1, pp. 37-48. Dor: 10.3406/quate. 1987. 1830.

Katsui, Y., H. Komuro, and T. Uda (1985). "Development of faults and growth of Usu-Shinzan cryptodome in 1977-1982 at Usu Volcano, North Japan". = Journal of the Faculty of Science, Hokkaido University. Series 4, Geology and mineralogy 21.3, pp. 339-362.
Kereszturi, G. and K. Nmeth (2012). "Monogenetic Basaltic Volcanoes: Genetic Classification, Growth, Geomorphology and Degradation". Updates in Volcanology - New Advances in Understanding Volcanic Systems. InTech. Dor: 10.5772/51387.

Kirschvink, J. (1980). "The least-squares line and plane and the analysis of palaeomagnetic data". Geophysical Journal International 62.3, pp. 699-718.

Magee, C., I. D. Bastow, B. van Wyk de Vries, C. A.-L. Jackson, R. Hetherington, M. Hagos, and M. Hoggett (2017). "Structure and dynamics of surface uplift induced by incremental sill emplacement". Geology 45.5, pp. 431-434. Dor: 10.1130/g38839. 1.

Martel, C., R. Champallier, G. Prouteau, M. Pichavant, L. Arbaret, H. Balcone-Boissard, G. Boudon, P. Boivin, J.-L. Bourdier, and B. Scaillet (2013). "Trachyte Phase Relations and Implication for Magma Storage Conditions in the Chaine des Puys (French Massif Central)". Journal of Petrology 54.6, pp. 10711107. Dor: 10.1093/petrology/egt006.

Mathieu, L. and B. van Wyk de Vries (2009). "Edifice and substrata deformation induced by intrusive complexes and gravitational loading in the Mull volcano (Scotland)". Bulletin of Volcanology 71.10, pp. 11331148. Dor: 10. 1007/s00445-009-0295-5.

McElhinny, M. W. and J. Lock (1995). "Four IAGA databases released in one package". Eos, Transactions American Geophysical Union 76.27, pp. 266-266. DoI: 10. 1029/95eo00158.

McFadden, P. L. and F. J. Lowes (1981). "The discrimination of mean directions drawn from Fisher distributions". Geophysical Journal International 67.1, pp. 19-33. DoI: $10.1111 /$ j . $1365-246 x .1981$. tb02729. $x$.

Merrill, R. T. and M. W. McElhinny (1983). The Earth's magnetic field: Its history, origin and planetary perspective. Vol. 401. Academic Press London.

Miallier, D., P. Boivin, C. Deniel, A. Gourgaud, P. Lanos, M. Sforna, and T. Pilleyre (2010). "The ultimate summit eruption of Puy de Dôme volcano (Chaine des Puys, French Massif Central) about 10, 700 years ago". Comptes Rendus Geoscience 342.11, pp. 847854. Dor: 10.1016/ j .crte.2010.09.004.

Miallier, D., T. Pilleyre, P. Boivin, and S. Sanzelle (2013). "L'éruption phréatomagmatique du Montchié, chaine des puys, Massif Central français (13, $6 \pm 1,0 \mathrm{ka})$ ". Quaternaire vol. 24/2, pp. 99-107. Dor: $10.4000 /$ quaternaire. 6512.

Miallier, D., T. Pilleyre, S. Sanzelle, P. Boivin, and P. Lanos (2012). "Revised chronology of the youngest volcanoes of the chaine des puys (french Massif central)". Quaternaire vol. 23/4, pp. 283-290. Dor: 10 . 4000 / quaternaire. 6367.

Michon, L. and O. Merle (2001). "The evolution of the Massif Central Rift; spatio-temporal distribution of the volcanism". Bulletin de la Societe Geologique de France 172.2, pp. 201-211. DoI: 10.2113/172.2.201. 
Minakami, T., T. Ishikawa, and K. Yagi (1951). "The 1944 Eruption of Volcano Usu in Hokkaido, Japan”. Bulletin Volcanologique 11.1, pp. 45-157. Dor: 10 . 1007 / bf 02596029.

Moore, J. G. and W. C. Albee (1981). "Topographic and structural changes, March-July 1980 Photogrammetric data". US Geological Survey Professional Paper, p. 123.

Nakada, S. (2018). "What should we do in Global Geoparks to reduce risks from geohazards". 8th International UNESCO Global Geopark Conference (Madonna di Campiglio, Italy), p. 62.

Németh, K. (2010). "Monogenetic volcanic fields: Origin, sedimentary record, and relationship with polygenetic volcanism". Geological Society of America Special Papers. Geological Society of America, pp. 43-66. DoI: $10.1130 / 2010.2470$ (04).

Okada, J., H. Sato, S. Mimatsu, J. Fontiela, and H. Okada (2016). "Long run communication support based on diagnostic symptom to the eruption as key roles of volcanologists toward sleeping giant-Case studies from Bandai, Usu and Azores". Cities on Volcanoes 9 (Puerto Varas, Chile). Vol. 9, pp. 20-25.

Özdemir, Ö. and D. J. Dunlop (2003). "Lowtemperature behavior and memory of iron-rich titanomagnetites (Mt. Haruna, Japan and Mt. Pinatubo, Philippines)". Earth and Planetary Science Letters 216.1-2, pp. 193-200. DoI: 10.1016/s0012$821 \times(03) 00481-3$.

Özdemir, Ö., D. J. Dunlop, and B. M. Moskowitz (1993). "The effect of oxidation on the Verwey transition in magnetite". Geophysical Research Letters 20.16, pp. 1671-1674. Dor: 10.1029/93gl01483.

Pagli, C., T. J. Wright, C. J. Ebinger, S.-H. Yun, J. R. Cann, T. Barnie, and A. Ayele (2012). "Shallow axial magma chamber at the slow-spreading Erta Ale Ridge". Nature Geoscience 5.4, pp. 284-288. Dor: 10 . 1038 /ngeo 1414.

Petronis, M. S., A. Delcamp, and B. van Wyk de Vries (2013). "Magma emplacement into the Lemptégy scoria cone (Chaine Des Puys, France) explored with structural, anisotropy of magnetic susceptibility, and Paleomagnetic data". Bulletin of Volcanology 75.10. DoI: 10. 1007/s00445-013-0753-y.

Portal, A., L.-S. Gailler, P. Labazuy, and J.-F. Lénat (2016). "Geophysical imaging of the inner structure of a lava dome and its environment through gravimetry and magnetism". Journal of Volcanology and Geothermal Research 320, pp. 88-99. Dor: 10 . 1016 / j . jvolgeores.2016.04.012.

Reeves, J., C. Magee, and C. Jackson (2018). "Unravelling intrusion-induced forced fold kinematics and ground deformation using 3D seismic reflection data". Volcanica, pp. 1-17. DoI: 10.30909/vol .01. 01.0117.

Shea, T., B. van Wyk de Vries, and M. Pilato (2007). "Emplacement mechanisms of contrasting debris avalanches at Volcán Mombacho (Nicaragua), provided by structural and facies analysis". Bulletin of Volcanology 70.8, pp. 899-921. DOI: 10 . 1007 / s00445-007-0177-7.

Tarling, D. and F. Hrouda (1993). Magnetic anisotropy of rocks. Springer Science \& Business Media.

Tobita, M., M. Murakami, H. Nakagawa, H. Yarai, S. Fujiwara, and P. A. Rosen (2001). "3-D surface deformation of the 2000 Usu Eruption measured by matching of SAR images". Geophysical Research Letters 28.22, pp. 4291-4294. Dor: 10.1029/2001gl013329.

Valentine, G. A., J. A. Cortés, E. Widom, E. I. Smith, C. Rasoazanamparany, R. Johnsen, J. P. Briner, A. G. Harp, and B. Turrin (2017). "Lunar Crater volcanic field (Reveille and Pancake Ranges, Basin and Range Province, Nevada, USA)". Geosphere 13.2, pp. 391438. Dor: 10.1130/ges01428. 1.

van Wyk de Vries, B., A. Márquez, R. Herrera, J. L. G. Bruña, P. Llanes, and A. Delcamp (2014). "Craters of elevation revisited: forced-folds, bulging and uplift of volcanoes". Bulletin of Volcanology 76.11. Dor: 10 . 1007/s00445-014-0875-x.

van Wyk de Vries, B., G. Tiu, S. Mossoux, M. Kervyn, and A. Lagmay (2012). "Structural control of the Limagne Rift Fault on the Chaine des Puys". AGU Fall Meeting Abstracts.

van Wyk de Vries, B. and D. Vereb V.and Karátson (2019). "Geosite inventories in World Heritage sites: essential for protection and management". Geophysical Research Abstracts (EGU General Assembly 2019, Vienna, Austria). Vol. 21. EGU2019-3604.

Verwey, E. J. W. (1939). "Electronic Conduction of Magnetite $\left(\mathrm{Fe}_{3} \mathrm{O}_{4}\right)$ and its Transition Point at Low Temperatures". Nature 144.3642, pp. 327-328. DoI: 10 . $1038 / 144327 \mathrm{~b} 0$.

von Buch, L. (1820). "Über die Zusammensetzung der baltischen Inseln und über Ehrebungs-Cratere". Abhandlungen der Königlichen Akademie der Wissenschaften, pp. 51-68. [In German].

Závada, P., Z. Kratinová, V. Kusbach, and K. Schulmann (2009). "Internal fabric development in complex lava domes". Tectonophysics 466.1-2, pp. 101-113. Dor: $10.1016 / \mathrm{j}$. tecto.2008.07.005.

Zijderveld, J. (1967). “A. C. Demagnetization of Rocks: Analysis of Results”. Methods in Palaeomagnetism. Ed. by D. Collinson, K. Creer, and S. Runcorn. Elsevier, pp. 254-286. DoI: 10 . 1016 / b978 - 1-4832 - 2894 $5.50049-5$. 


\section{A Appendix 1}

\section{Anisotropy of Magnetic Susceptibility Methods and Results and Rock Magnetic DATA}

\section{A.1 Analytical Methods}

Anisotropy of magnetic susceptibility (AMS) measurements of a rock specimen yield an ellipsoid of magnetic susceptibility $(\mathrm{K})$ defined by the length and orientation of its three principal axes, $\mathrm{K}_{1} \geq \mathrm{K}_{2} \geq \mathrm{K}_{3}$, which are the three eigenvectors of the susceptibility tensor [Tarling and Hrouda 1993]. The long axis of the magnetic susceptibility ellipsoid, $\mathrm{K}_{1}$, gives the magnetic lineation, while the short axis, $\mathrm{K}_{3}$, defines the normal to the magnetic foliation plane $\left(\mathrm{K}_{1}-\mathrm{K}_{2}\right)$. The bulk magnetic susceptibility $\left(\mathrm{K}_{m}\right)$ is the arithmetic mean of the principal axes $K_{1}, K_{2}$, and $K_{3}$ [see Jelinek 1981; Tarling and Hrouda 1993]. We measured the AMS of 332 specimens prepared from samples collected at 17 sites distributed throughout the study area. The AMS measurements were performed on an AGICO MFK1-A multi-function kappabridge operating at low alternating field of $200 \mathrm{~A} / \mathrm{m}$ at $976 \mathrm{~Hz}$ at the New Mexico Highlands University Paleomagnetic-Rock Magnetic laboratory. The AMS results and the susceptibility parameters are summarized in Table A1. 
A.2 Anisotropy of Magnetic Susceptibility Results

Table A1 - Anisotropy of Magnetic Susceptibility Data from the Puy de Dôme

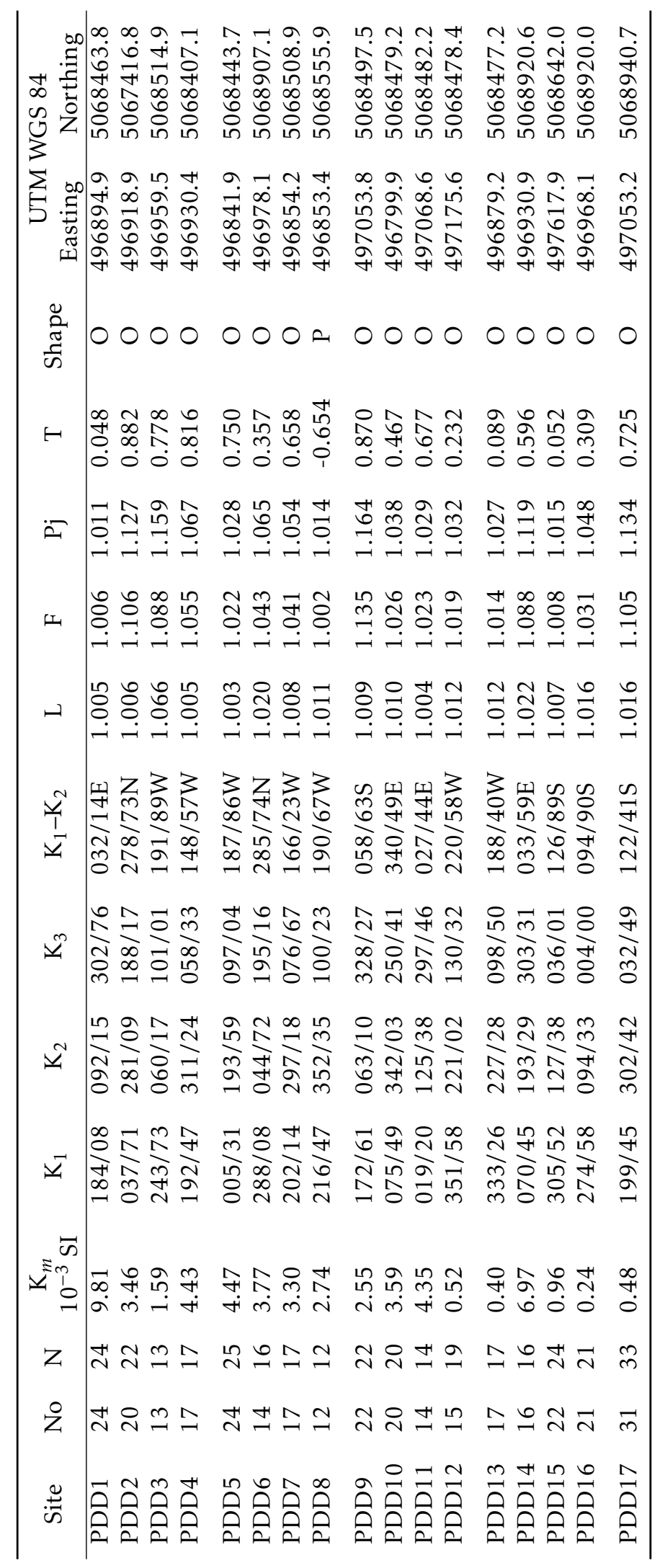



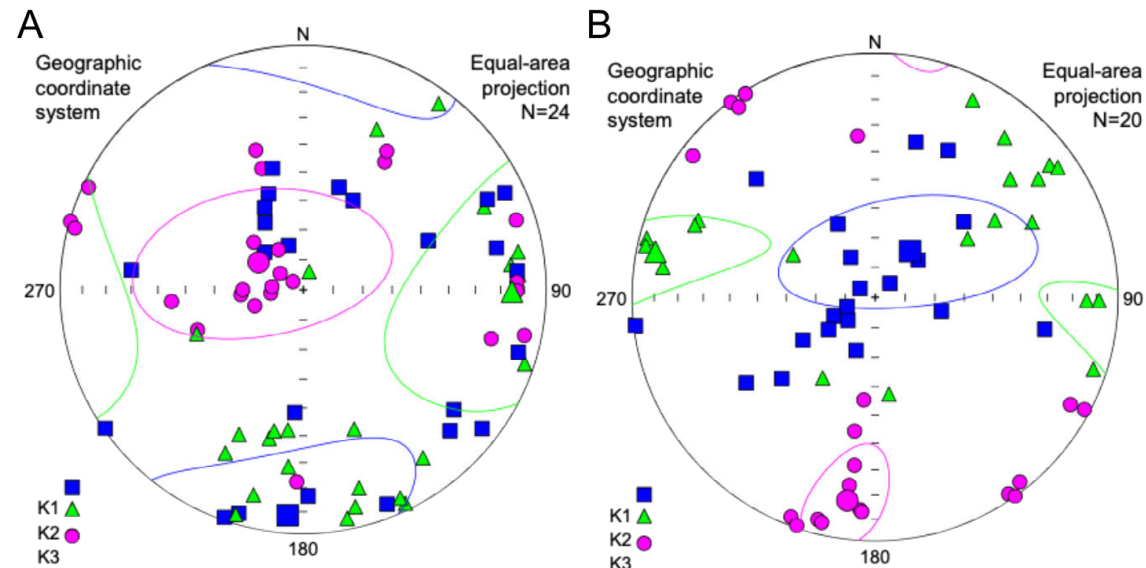

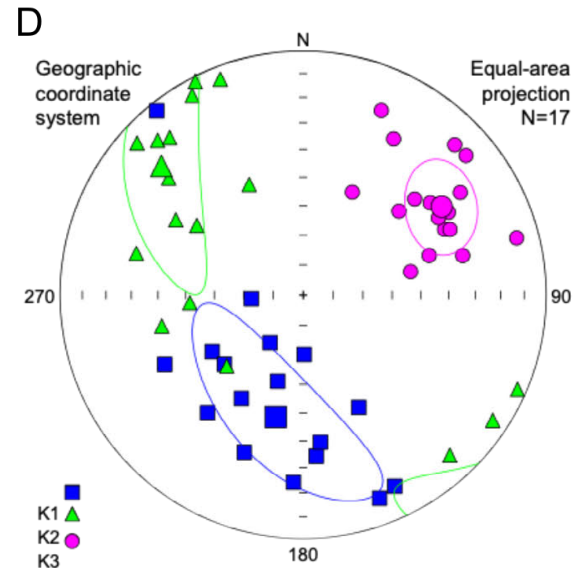

E

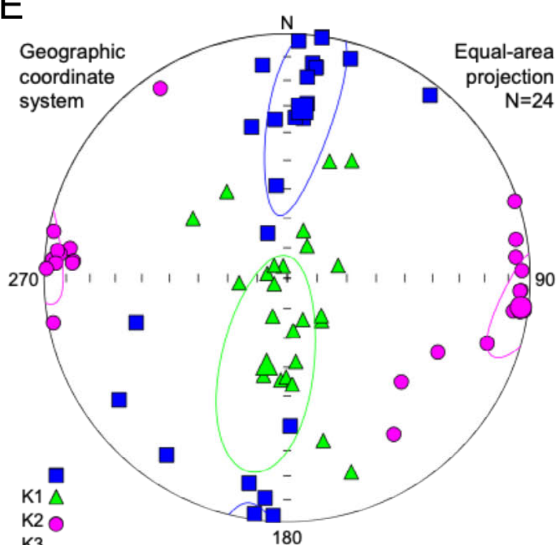

$\mathrm{H}$
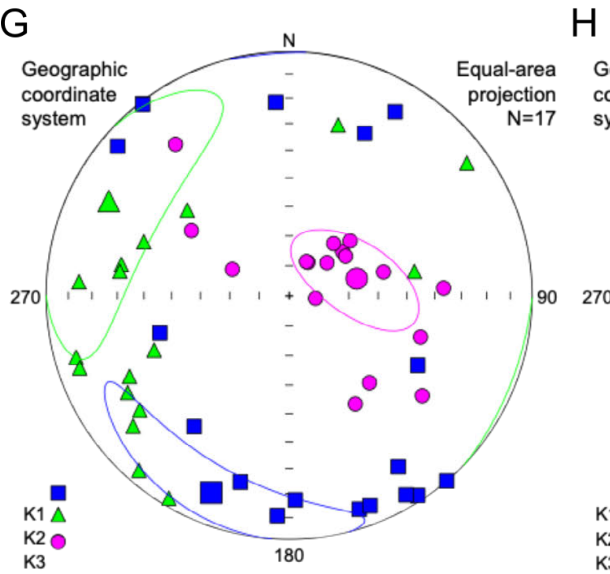

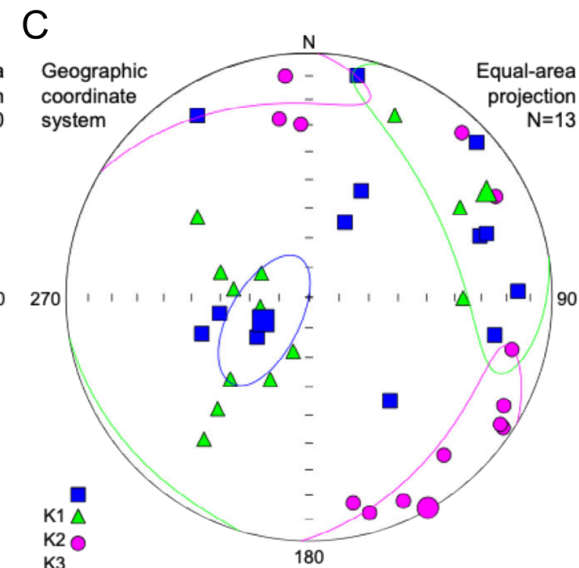

C

$\mathrm{F}$

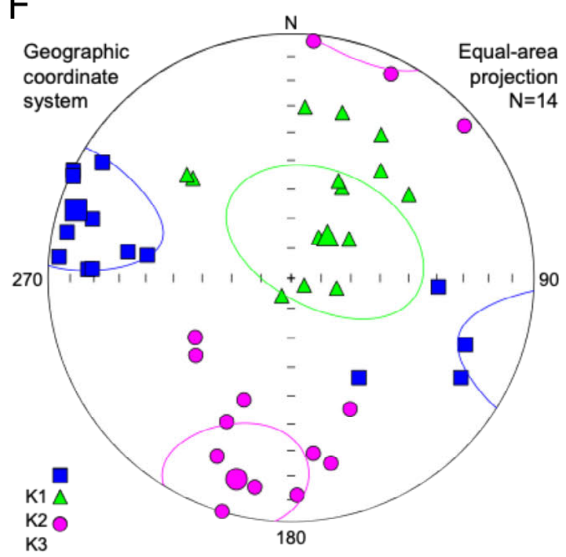

I

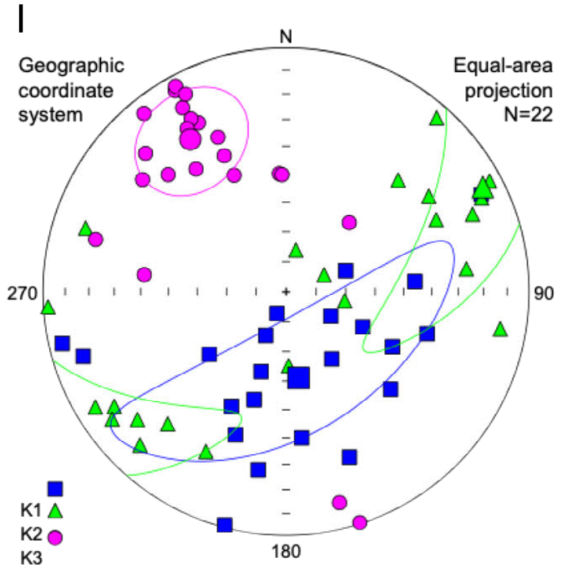

Figure A1: Anisotropy of Magnetic Susceptibility results for [A] PDD1; [B] PDD2; [C] PDD3; [D] PDD4; [E] PDD5; [F] PDD6; [G] PDD7; [H] PDD8; [I] PDD9. 


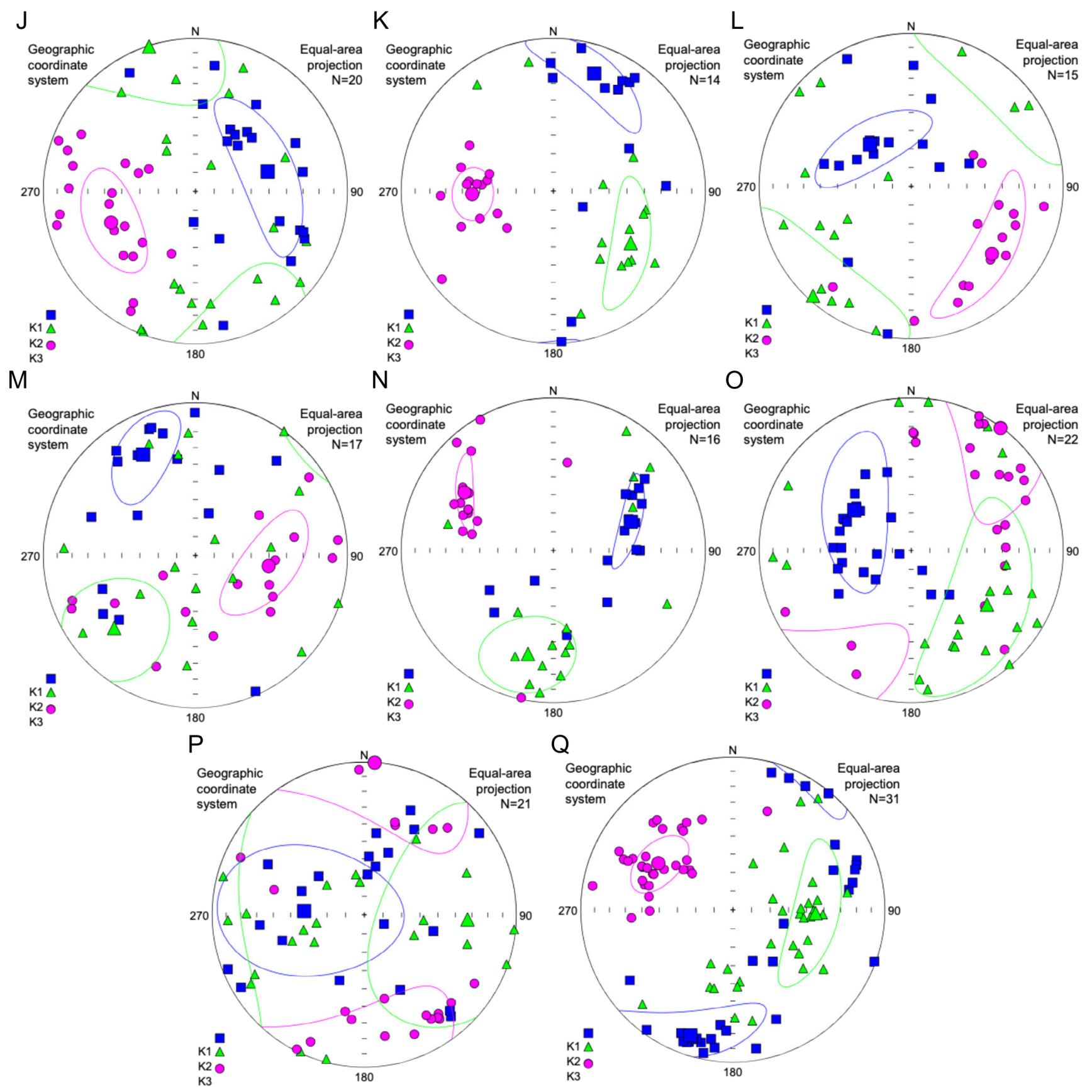

Figure A1: [cont.]: Anisotropy of Magnetic Susceptibility results for [J] PDD10; [K] PDD11; [L] PDD12; [M] PDD13; [N] PDD14; [O] PDD15; [P] PDD16; [Q] PDD17. 
A.3 Rock Magnetic Results

A.3.1 Isothermal Remanent Magnetization Results

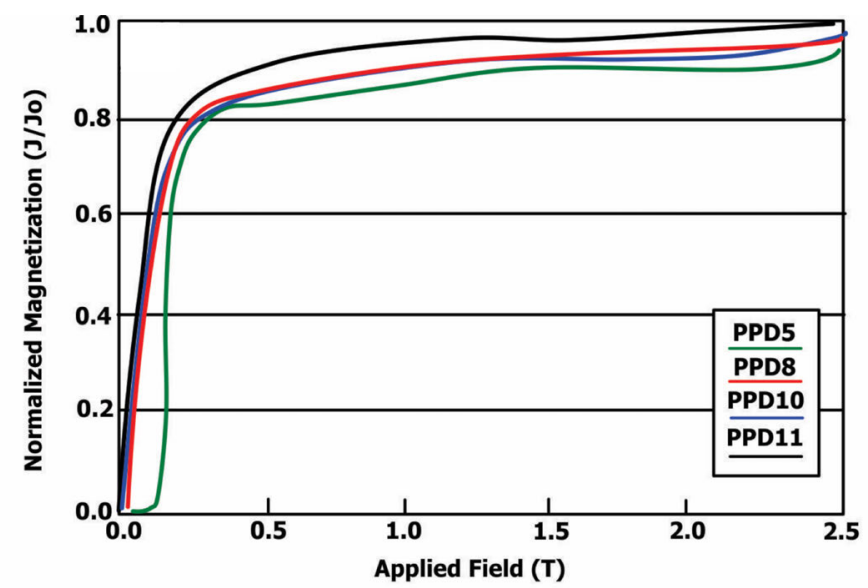

Figure A2: Isothermal Remanent Magnetization Results

A.3.2 Low Temperature Remanence Experiments

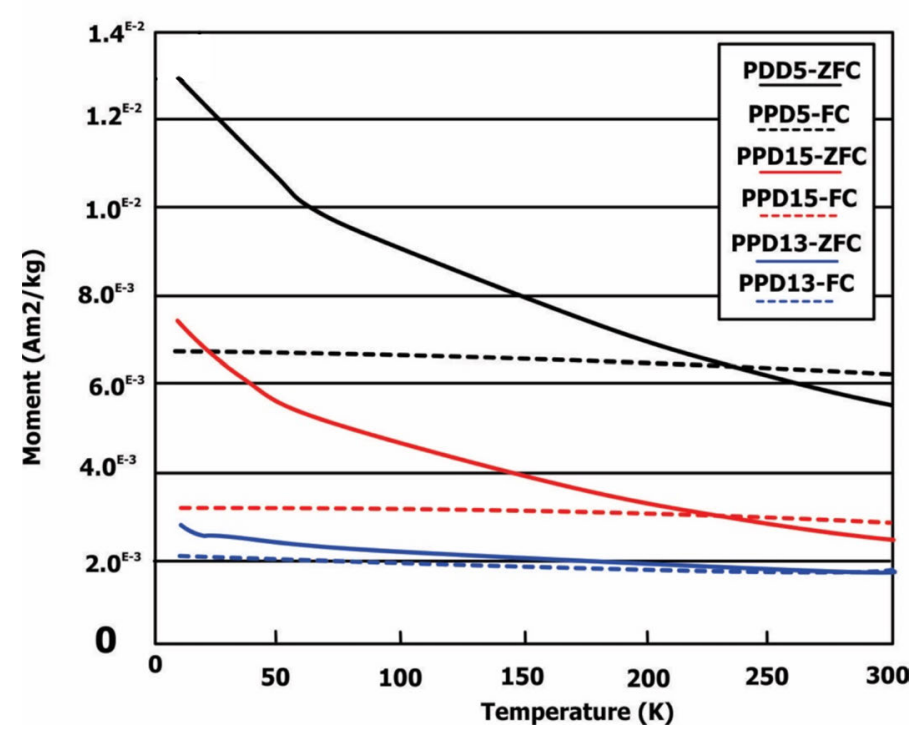

Figure A3: Low Temperature Remanence Results

\section{A.3.3 Curie Point Estimates}

Table A2: Curie Point Estimates

\begin{tabular}{ccccc}
\hline Site & Low temperature & Inflection point & Hopkinson peak & Ti-content \\
\hline PDD - 1C & - & 558 & $499^{*}$ & 0.1360 \\
PDD - 2D & - & $576^{*}$ & - & 0.0110 \\
PDD - 3F & - & $582^{*}$ & - & 0.0005 \\
PDD - 4B & - & $582^{*}$ & $386^{*}$ & 0.0005 \\
PDD - 5K & 289 & $584^{*}$ & - & 0.0028 \\
PDD - 6H & - & $494^{*}$ & - & 0.1440 \\
PDD - 7L & - & $491^{*}$ & - & 0.1480 \\
PDD - 8A & - & - & $488^{*}$ & 0.1450 \\
PDD - 9E & - & $588^{*}$ & - & 0.0094 \\
PDD - 10J & - & $574^{*}$ & - & 0.0140 \\
PDD - 12G & 267 & - & $477^{*}$ & 0.1710 \\
PDD - 13J & 425 & 587 & $513^{*}$ & 0.1140 \\
\hline
\end{tabular}



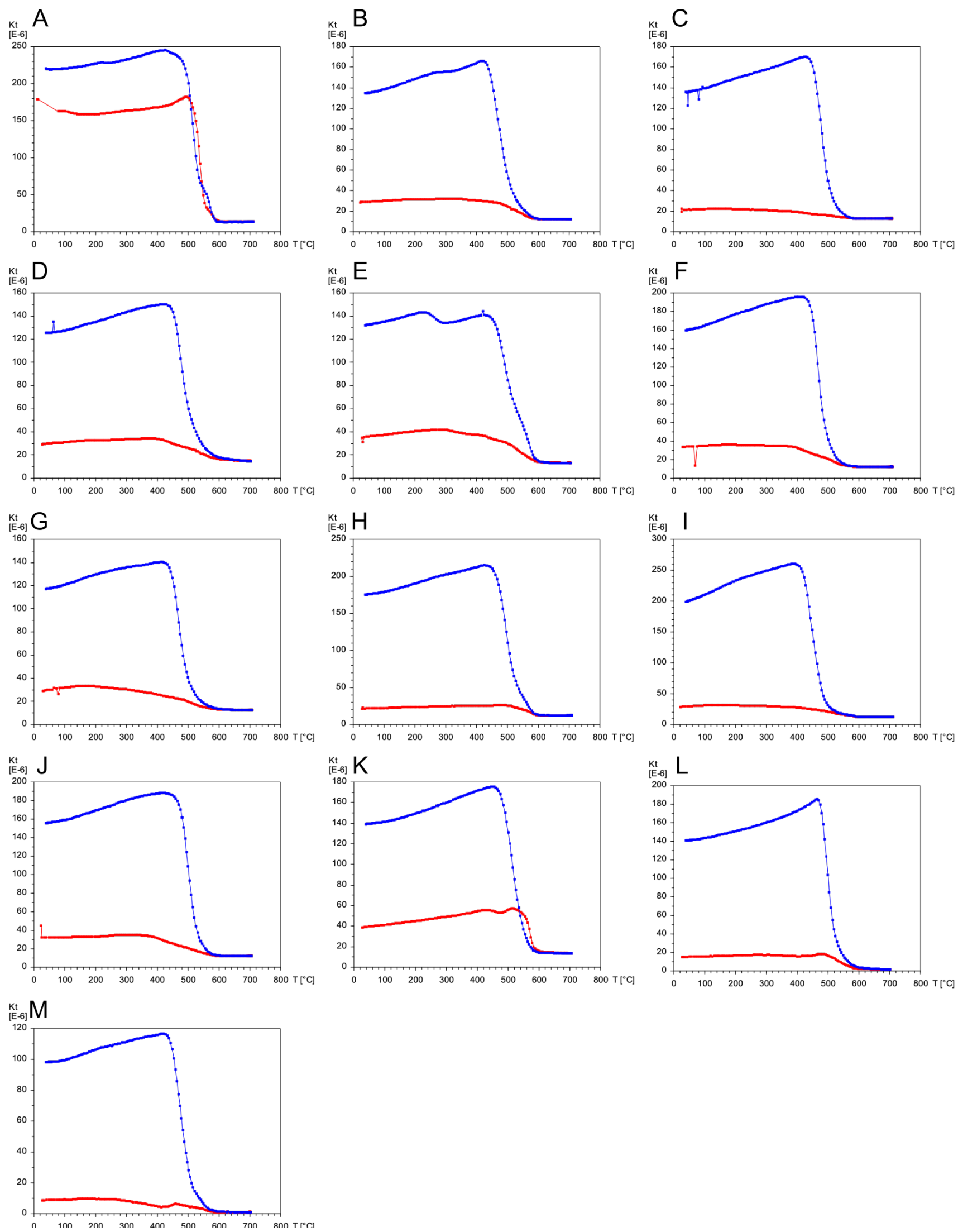

Figure A4: Curie Point Estimate Heating-Cooling Diagrams for [A] PDD - 1C; [B] PDD - 2B; [C] PDD - 3F; [D] PDD - 4B; [E] PDD - 5K; [F] PDD - 6H; [G] PDD - 7L; [H] PDD - 8A; [I] PDD - 9E [J] PDD - 10J; [K] PDD - 11P; [L] PDD - 12G; [M] PDD - 13J. 